\title{
Quantitative Estimation of Altimetric Variations Using Residual DEM from Topographical Maps between Two Epochs 1893 and 1985: Case Study: The Endorheic Basin of Enfidha-Tunisia
}

\author{
Noamen Rebai* (D), Abdelkader Moussi ${ }^{(1)}$ \\ University of Tunis El Manar, National School of Engineering of Tunis, LR14ES03 Geotechnical Engineering and Georisk \\ Laboratory, Tunis, Tunisia \\ Email: *noamen.rebai@enit.utm.tn
}

How to cite this paper: Rebai, N. and Moussi, A. (2019) Quantitative Estimation of Altimetric Variations Using Residual DEM from Topographical Maps between Two Epochs 1893 and 1985: Case Study: The Endorheic Basin of Enfidha-Tunisia. Journal of Geographic Information System, 11, 429-456.

https://doi.org/10.4236/jgis.2019.114027

Received: May 9, 2019

Accepted: August 9, 2019

Published: August 12, 2019

Copyright $\odot 2019$ by author(s) and Scientific Research Publishing Inc. This work is licensed under the Creative Commons Attribution International License (CC BY 4.0).

http://creativecommons.org/licenses/by/4.0/

\begin{abstract}
This article endeavours to analyse the recent deformation in the Enfidha region. This analysis has been carried out using the Residual Digital Elevation Model (DEM). It is the altimetric difference between two DEM generated from the contour lines of two topographical maps over a period of 100 years. This deformation has been studied by some authors who report the presence of recent ground movements by comparing contour lines with a downward trend in elevation from 1893 to 1985. In 2006, this study area was marked by the presence of two earthquakes that occurred in several coastal cities located in the northeastern part of Tunisia. Our study involves a quantitative estimation of altimetric variations under a Geographic Information System (GIS) environment. Our proposed methodology aims at the mapping of residual (DEM) and the extraction of parameters that have a morphological and morphostructural signature. The extraction of quantitative morphostructural parameters requires the integration of multi-source and multi-scale data. This can only be done if the problem of heterogeneity at the level of scale and coordinate system is solved through the use of GIS tools and the obtainment of the vectorial shapefile format. Then, in order to compare the DEM generation errors with reference to recent and old data, they must be projected in the same projection system and on the same scale. The available data are two topographic maps of Enfidha which represent two different epochs. The first one is an old topographic map of 1893 (type 1922) at a scale of 1:50,000 and the second one is a recent topographic map of 1985 at a scale of 1:25,000. These topographical maps have the Lambert (IGN) projection system. This
\end{abstract}


methodological approach, based on residual (DEM), allows to highlight an

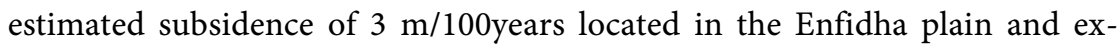
tends to the south coast of Cap Bon area in Tunisia. The variation of the contour lines shape between the old and the recent map can be studied in correlation with a relay structure fault observed and recognized by some analysts in this area. These relay accidents remain active according to the results obtained by the residual (DEM) and validated by the field observations of two sites that we have carried out in the Enfidha endorheic basin.

\section{Keywords}

Recent Deformation, Residual Digital Elevation Model (DEM), Geographic Information System (GIS), Topographical Maps, Enfidha's Endorheic Basin

\section{Introduction}

Since the early orogenic phases, the Tunisian Sahel region and its foreland have recorded distinct cycles of uplift, erosion and displacement estimated displacement estimated in some regions at a few hundred metres [1] [2]. The repeated folds generally result from maximum compressive stresses oscillating between an NW-SE pole [3] [4] [5] and an NS pole [6] [7]. This causes the individualization of a complex system of folds and evolves integrally in the molded faults on the faults solicited by the same compressions. The generated structures are always altered by an intense erosion that gives these folded structures their geomorphological imprints. These imprints can be observed and analyzed using the different hydrographic networks that cross them. These networks, once plotted on a topographic map, allow to qualify and quantify the tectonic movements deployed over a given period of time. In our case, this period is about 100 years. This work has four main objectives: 1) to measure, using morphometric indices, the amplitude of the movements responsible for the collapse of the endorheic basin of the Enfidha region 2) to develop a morphological pattern in line with that of the tectonics of the region 3) to present an evolutionary scenario of this region compatible with the general geodynamic framework of the Atlasique $\mathrm{Tu}$ nisie 4) and to relate this evolution with that observed in the western Mediterranean during the quaternary period [8] [9]. To achieve these objectives, we have collected data from the analysis of a Digital Elevation Model (DEM) of two topographic maps with two different periods from 1893 (type 1922) at the 1/50,000 scale and from 1985 at the $1 / 25,000$ scale with the Lambert (IGN) projection system. The validation of recent deformation is done by direct observation in the field. This is only possible in the GIS environment and the use of GIS tools that enable the shapefile vector format to solve the problem of heterogeneity, superposition and application of mathematical operators. The various studies carried out using morphometric index and structural analyses [10]-[21] indicate that the DEM, the hydrographic network can significantly determine the existence of 
tectonics or erosion. In the present work, we are interested in quantifying and highlighting the recent deformation by applying a comparative approach to the DEM of two topographic maps from 1985 to 1893 . The assessment of the results is carried out through field observations in two sites. Essentially, a methodological approach has been developed in this context. It is based on the residual (DEM), which corresponds to an arithmetical difference of two DEM.

\section{The Studied Area}

\subsection{The Geomorphological Context}

Enfidha region is situated between Zaghouan mountain range and the sea. It is located in the middle of a plain in the Tunisian Sahel.

The study area (Figure 1) is characterized by low relif areas between $10 \mathrm{~m}$ and $170 \mathrm{~m}$. It covers an area of $82.9 \mathrm{~km}^{2}$ and $37.07 \mathrm{~km}$ perimeter and is limited to a rectangle defined by the following geographical coordinates: 11.445073E; $11.581343 \mathrm{~W}$ and $40.180091 \mathrm{~N} ; 40.104110 \mathrm{~S}$. To the northeast, this region is distinguished by the outcrop of a range of structural massifs (El Ogla, Garci, Medhker and Fadhloun Mountains). To the southeast, however, it is identified by a spreading plain.

\subsection{The Geologic Context}

The Oligocene facies distribution throughout the sandstone pole and the carbonate pole in the Sahel and in offshore domains [22] reveals some latitudinal and longitudinal lineaments. In the Tunisian Sahel eastern margin, along with the Gulf of Hammamet and Cape Bon, the Miocene and Pliocene sedimentary series are most often buried below the surface. In the northeastern Sahel, the Miocene and Pliocene basins are also characterized by synclinal gutter formation associated with folded structures along the EW tectonic corridors of El Haouaria, Tazoghrane, Hammamet-Maamoura and the N-S of Jriba-Enfidha [23].

Until today, The study area was also marked by the predominance of Quaternary deposits with recent soils and alluvium occupying the Enfidha plain and the mountain foothills, as well as the oligo-Mio-Pliocene sandstone deposits (Figure 2).

Significantly, the study area includes the Enfidha block [7] [24], which corresponds to a folded and faulted zone. The geologic structures of Enfidha are closely associated with the N-S axis [25]. Thus, this axis limits our sector from the west. It corresponds to a deep suture due to the heterogeneity of the bedrock [25]. This axis separates a stable area in the East from another unstable area in the West [25]. It is due to the reduction in the atlasic direction folds (NE-SW) which become NS as they approach the Haffouz-Kairouan area in the south [25]. Towards the east of this N-S axis, oriental plains are developing, dominated by Mio-plioquaternary outcrops [23] [26] [27] [28]. In this way, the processing and interpretation of petroleum seismic profiles, seismic profiles, gravity data and 


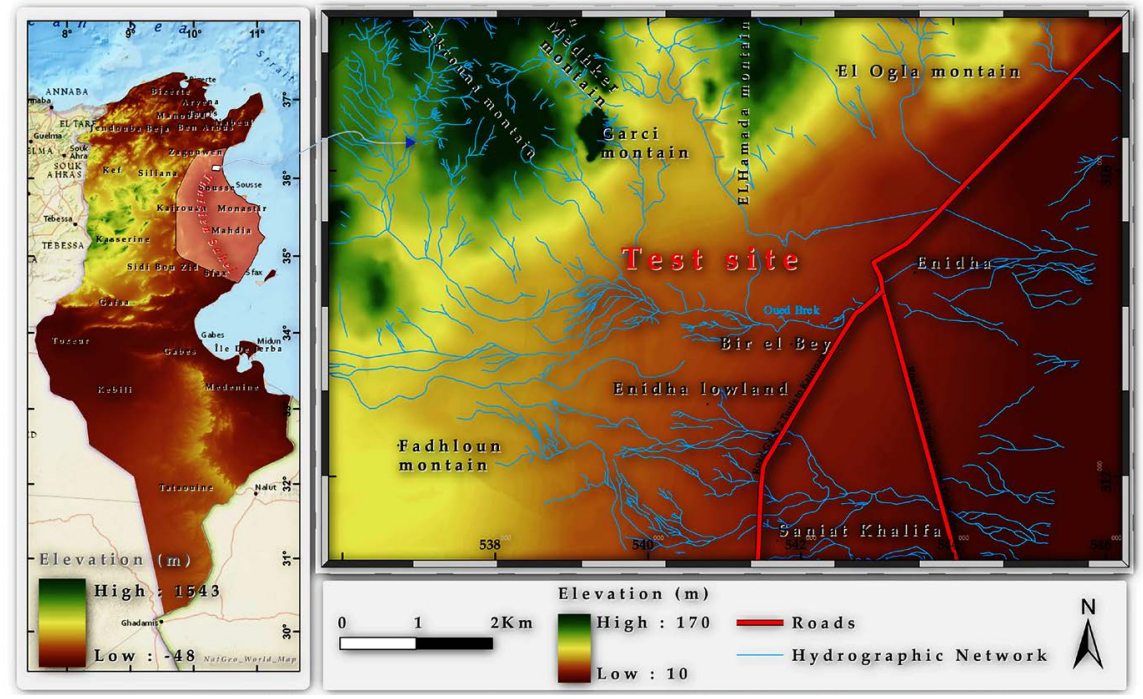

Figure 1. The geographical setting of the study area.

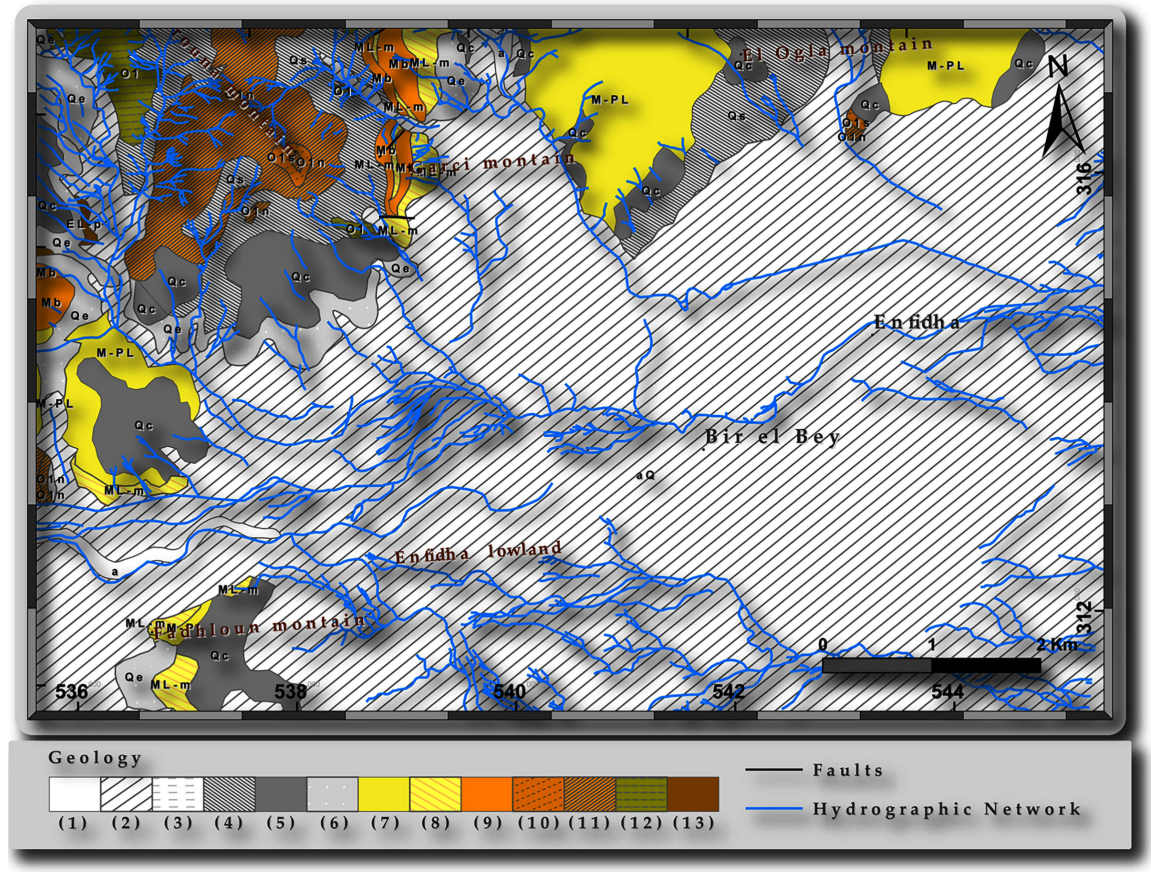

Figure 2. The geologic setting of the study area. (1) Recent alluvium; (2) Old alluvial deposits; (3) Soils and Sebkha; (4) Soils; (5) Crust and crusting; (6) Screes; (7) Conglomerates, sandstones and clays; (8) Sandstone with clays; (9) Sandstone limestones in Lumachelles; (10) Fine sand, sandy clay and ferruginous sandstone; (11) Nummullites and clay sandstone alternation; (12) Marly clays and sandstone; (13) Gray-green marl.

surface data have permitted some authors [23] [24] [29] [30] [31] [32] [33] to demonstrate that in the subsurface, the area is very fractured and pull-apart basins associated with strike-slip corridors are developed [34]. The installation of inherited fault corridors, following the directions E-W, NW-SE, NE-SW and N-S control the basin fillings [34]. Other authors [24] [27] [35] [36] [37] have given the E-W fault an important role in the eastern of Tunisia. The study area is 
located in the eastern platform which is characterized, during the Mesozoic period, by a slower and more active subsidence during the Cenozoic period. The style of its deformation is essentially marked by the play of horsts and grabens, associated with folds of a large curvature radius [38]. The tectonic deformations recognized by seismic data in depth [23] [39] affect only narrow, elongated areas oriented in three major directions: N45, N100-120 and N160-180. These zones, which are active at several geologic and tectonically complex times, delimit large areas with few or no deformations [38]. The Miocene deformation is much less intense than in the other parts of Tunisia. Indeed, the eastern platform is only affected by the N45 direction folds, often accompanied by reverse faults and associated with the N90-110 dextral and N160-180 senestral faults [39]. The Plio-Quaternary deformation proofs are recognized outcrops in small areas, most often in the extension of the Atlas structures and as a result of accidents detected by seismic reflection [39]. This deformation is represented by a succession of dissymmetrical anticlines, with straightened NW flanks, and by N90 dextral and N160 senestral strike-slip, all probably due to pre-existing accidents [39]. According to [30], in the further east of Zaghouan accident and precisely 40 kilometres away, is located the new overlapping front of the Atlas Mountains of Tunisia. This is a NNE-SSW to North-South accident, connecting Chrichira in the south, to Enfidha in the north along more than $100 \mathrm{~km}$ [30]. On the other hand, since 1922, a seismological survey has been established in the country since 1922 and developed later, in 1976 and 1985, by the National Institute of Meteorology (NMI) of Tunisia. The seismicity of major Tunisian events does not exceed a magnitude of 6.8. In the Tunisian Sahel sector, two earthquakes were felt in (2006) in several coastal cities of the North-East and affected several regions, including Nabeul, Saouaf, Ennadhour, Essalloum, Enfidha, the southern districts of the city of Tunis and Monastir (2013), thus marking the presence of the recent deformation.

\section{The Background and Purpose of the Study}

The context of this study is essentially based on [40] previous work, develops a the comparative examination of the isohypses of the old Enfidha topographic map ( $n^{\circ} 43,1 / 50,000$, lifted in 1892), the new Enfidha NE topographic sheets ( ${ }^{\circ} 43-\mathrm{NE}, 1 / 25,000$, published in 1990) and the topographic surveys of the railway level control at entrance of the city. According to a conventional approach and with recourse to multisource data, this comparison permits us to remark that in the Enfidha plain, the contours are clearly shifted upstream. This displacement expresses a downward revision of the equivalent altitudes of a subsidence trend. This phenomenon is apparent the case of the Enfidha plain, around Sebkhet el Kelbia and Bled Saadia (Jbibina sheet, $n^{\circ} 48$ ) [40].

This study focuses on the implementation of a methodological approach (Figure 3) based essentially on both the use of digital topographic data (contour lines, hydrographic network) and the generation of DEM in a GIS environment. 


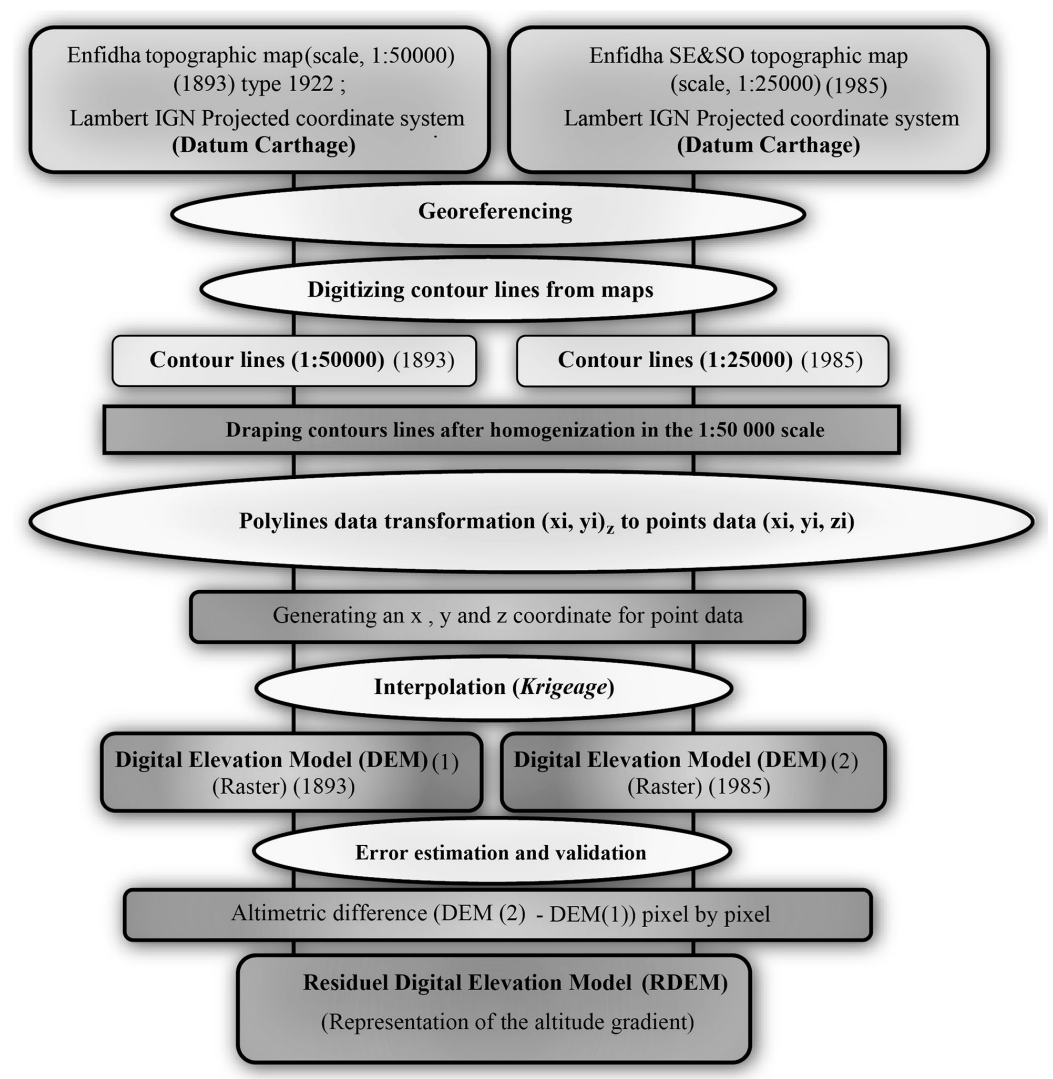

Figure 3. The methodological approach to the generation of a residual DEM to analyze recent deformations through map data (contour lines) from 1893 and 1985.

The purpose of this analysis is to quantitatively study recent deformations in the study area and thus to understand how land subsidence is affected in Enfidha. Accordingly, it seems necessary to validate the current tectonic accidents of the Oligocene by field observations and to control the morphology of the soil in certain sites under study. Two topographic maps are used of Enfidha. The old topographical map of Enfidha type 1922, sheet $n^{\circ} 43$, scale 1/50,000, raised in 1893. The two sheets of Enfidha SE and SW ( $\mathrm{n}^{\circ} 43,1 / 25,000$, published in 1985), photogrammetric surveys of 1981 (completed in 1984). The geologic data, extracted from the 1/50,000 geologic map (National Office of Mines) of 1974, and field observation data are also used in this study.

\section{Methodological Approach}

Our methodological approach presented by the flowchart (Figure 3), is based mainly on the generation of residual (DEM) in a GIS environment that makes possible the processing of spatial information and the estimation of the altimetric variation in the Enfidha lowland.

\subsection{Data Homogenization}

\subsubsection{Scanning Topographic and Geologic Maps}

The resolution of the scan affects the quality of the digitization afterwards, espe- 
cially when using documents on a large scale; where the boundaries of buildings, roads, etc. can be "incorrectly" reproduced. However, the use of a very high resolution is not always necessary since it is impossible to exceed the accuracy of the initial document, and moreover the size of the scanned document becomes more difficult to handle with a computer later on. In general, a resolution between 250 dot per inch and 300 dot per inch is sufficient.

Paper topographic and geologic information, supplied by the (Office of Topography and Cartography and National Mining Office), were scanned directly to RGB color TIFF files using a high-resolution, large format drum scanner at an optical resolution of $300 \mathrm{dpi}$.

\subsubsection{The Georeferencing Process}

The first step in georeferencing, or warping, the TIFF was to generate a neatline coverage with precise corner coordinates. A preexisting neatline or index grid could also be used as a reference. Georeferencing process allows the image to be displayed in a precise coordinate system and cartographic coordinates to be used to assign a spatial location to map features. Finally, all the elements of a map layer have a specific geographical position and extent that allow them to be located on or near the earth's surface.

The digitized topographic of both 1893 and 1985 and geologic maps were geo-referenced in the ArcMap environment using the kilometric grid of the Lambert North Tunisia coordinate system. An error measurement (residual error) is returned when the general formula (polynomial transformation) is calculated and applied to the control point. This error is the difference between the final position of the origin point and the actual position specified (destination point). The total error is calculated using the root mean square errors (RMSE) of all residues. This value describes the homogeneity of the transformation between the different control points (links).

\subsubsection{The Digitization Process}

A blank shapefile was created for every topographic and geologic GIS layer before digitizing began. The next operation concerns the digitization of contours lines from the three maps of Enfidha, one of 1893 at 1/50,000 and two SW/SE maps of 1985 at 1/25,000 under the ArcGis software. Similarly, the geologic map is digitized to present the lithological formations and site locations of field observations used to validate the obtained results with respect to the altitude variation between two periods of 1893 and 1985 by the residual (DEM). ESRI ArcGIS version 10.2.2 software was used, as well as various vector data formats (ArcInfo covers, shape files and geospatial databases) and raster images (ArcGrid, TIFF) to perform the conversion. During the completion of the project, geodatabase topological tools were used as (must not self intersect) for contour lines and (must not have gaps and must not overlap) for geologic formation contacts.

\subsubsection{The Homogenization of the Scale Map}

This operation concerns the homogenization of the scale by adjusting the two 
topographic maps (SW, SE at 1/25,000 scale) to $1 / 50,000$ scale. As is known, the $1 / 25,000$ map contains more detail than the $1 / 50,000$ map so it is more reasonable to make the transition from $1 / 25,000$ to $1 / 50,000$ scale without loss of information that is not possible otherwise, where you cannot add and provide non-existent details to the $1 / 25,000$ scale map. In fact, the applied treatment is based on the transition from the $5 \mathrm{~m}$ equidistance, of the topographic map at a scale of $1 / 25,000$, to the $10 \mathrm{~m}$ of the topographic map at a scale of $1 / 50,000$. This treatment is based on the spatial request by the selection of $10 \mathrm{~m}$ countour line interval and not $5 \mathrm{~m}$ of the 1/25,000 map. This process provides the same contour lines configuration of the $1 / 50,000$.

\subsection{The Overlay and Comparison of the Contours of the Two Topographic Maps}

After having completed the digitization of the contour lines of the old 1893 sheet and those of the recent 1985 sheets and the homogenization of the $1 / 50,000$ scale, we have systematically superimposed the backgrounds of all the sheets in these two contour lines.

The comparative examination indicates a shift, especially in the Enfidha plain. The contour lines are completely parallel and the contour lines (10, 20, 30 and 40 m) of 1985 are moving to the west (Figure 4).

The contours are clearly defined upstream. This displacement expresses a downward revision of the equivalent altitudes of a downward trend in the land.

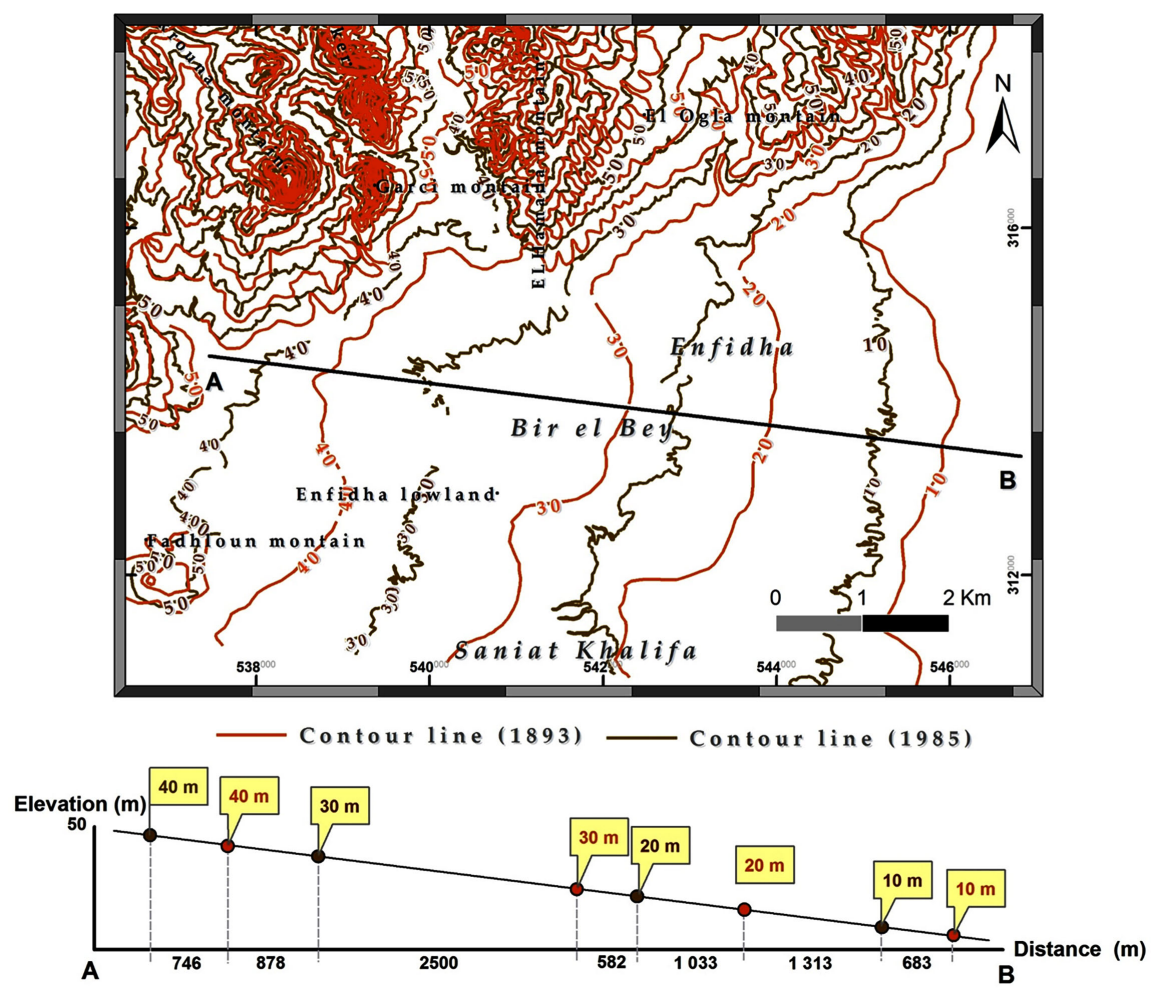

Figure 4. The topographic profile (AB) shows the position of the 1893 and 1985 contour lines and the decrease in elevation according to distance. 
The intersection points in the topographic profile (AB) (Figure 4) with the contours of two maps between two epochs show the subsidence and westward shift of the 1985 contours, which can reach a distance of $2500 \mathrm{~m}$.

\subsection{The Generation and Validation of DEM}

Based on cartographic modelling that involves an ordered sequence of elementary GIS operations on maps operating on raw data as well as on derived data, the aim is to stimulate a spatial modelling process [41].

In fact, Digital Elevation Models provide true terrain configuration information in the form of morphometric and topographic parameters [13] [14] [16] [18] [42] [43] [44], that can be used for both geomorphic and tectonic purposes, as in the case of the study of recent deformation [15] [18] [20] [44]-[50]. The DEM induces direct and indirect information (in the form of morphometric parameters) [20] [45] [47] [51] about the behavior of not only of the relief and its variations but also the hydrographic network [18] [20] [45] [47].

\subsubsection{The Performance of Error Statistics and the Evaluation of the Accuracy of the DEM}

Thus, the data obtained by digitizing the contour lines on the various topographic maps can be transformed into a (unique) database.

The study area topographic data that is available in a vector format for the study area is derived from the digitization of the topographic map of the Enfidha region at a scale of 1:50,000 with a surface equidistance of $10 \mathrm{~m}$ and a digitization of the map at a topographic scale of 1:25,000 with a surface equidistance of $5 \mathrm{~m}$. To analyze them, after the homogenization of the scale at $1 / 50,000$, these vector data in the form of linear contour lines composed by 83 contour lines for the 1893 map and by 98 contour lines for the 1985 map are transformed into an equidistant "point" database of $5 \mathrm{~m}$, composed of 44,629 points (for the topographic map "type 1922" 1893) and 43,250 points (for the 1985 topographic map) with altitudinal values in format ( $x i, y i, z i)$ (Table 1$)$.

The statistical results analysis (Figure 5 ) shows relatively symmetrical distributions $(S k>0)$ associated with a leptokurtic orography [52], uniformly distributed orographic volumes and ridge lines developed with very pronounced topographic maxima. A positive kurtosis $(K s>3)$ indicates that the tails allow more observations (Figure 5(a)). Asymmetric distributions (Figure 5(b)) on the left $(S k>0)$ and $(K s<3)$ are associated with a platykurtic orography [52].

Table 1. The Kriging statistical parameters for the point topographic database.

\begin{tabular}{cccccccc}
\hline & & Min & Median & Mean & Max & RMSE & me \\
\hline 1985 & $Z$ & 10 & 60 & 59.15 & 170 & & -0.011 \\
& $z i$ & 8.96 & 59.10 & 59.16 & 181.23 & & \\
1893 & $Z$ & 10 & 60 & 64.91 & 170 & & 0.014 \\
& $Z i$ & 9.37 & 61.07 & 64.89 & 179.34 & & \\
\hline
\end{tabular}



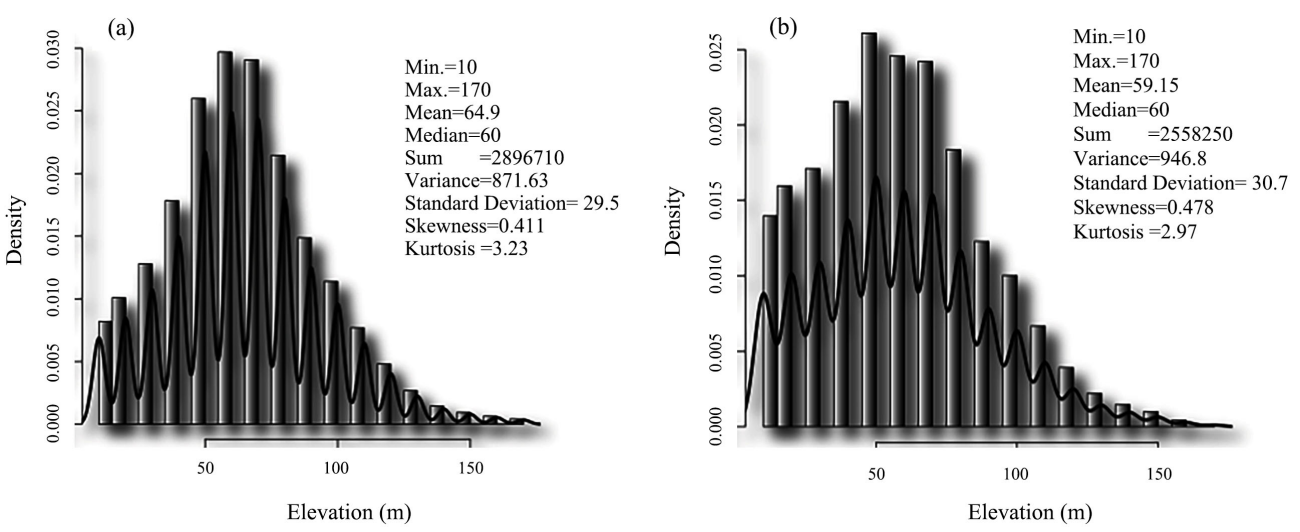

Figure 5. The elevation density histograms (a): 1893 and (b): 1985.

At this stage of processing, we are interested in evaluating the altimeter accuracy of the DEM in raster format. The inherent anomalies of interpolation methods can be optimized by adopting the best spatial interpolator. Several statistical methods can be used (inverse distance weighting, minimum curvature, natural neighbor, kriging, etc.) to evaluate the DEM's accuracy.

The external validation method (with control data), described by [45], assesses the quality of a parameter noted $z$, corresponding to any local parameter that can be extracted from the DEM of $\mathrm{n}$ control points, knowing that the first parameter generally evaluated is the elevation. The assessment in point $i$ is noted $\hat{z} i$. The value of the control data at this point is noted $z i$. The most commonly used measure is the Root Mean Square Error noted RMSE [53] [54] [55]. The RMSE equation can be expressed as (1):

$$
R M S E=\sqrt{\frac{1}{n} \sum_{i=1}^{n}(\hat{z} i-z i)^{2}}
$$

This measure can be specified by the systematic error (or bias) $R M S E^{2}$, corresponding to the mean error (arithmetic) noted me (mean error), and the random error noted $\sigma$, which corresponds to the standard deviation of the error [45] [53] [56]. The three variables are linked by the following relation (2):

$$
R M S E^{2}=m e^{2}+\sigma^{2}
$$

with an average of errors defined as follows (3):

$$
m e=\frac{1}{n} \sum_{i=1}^{n}(\hat{z} i-z i)
$$

According to [57], for the internal validation (without control data), the DEM's compliance with landforms can be controlled by visualizing the parameters derived from the surface because they are more sensitive to the accuracy of the altitude values and artifacts of the interpolation method than at the altimetric level. [58] also proposes to visualize the result of the DEMs filtering (for example a Laplacian filter to detect the objects contours). The quality of a DEM depends essentially on a series of choices made during the construction of this DEM. These choices concern both the basic data used to obtain all the reference 
points and the final format [45] [59]. Indeed, it can be analyzed with regard to genealogy (source data, acquisition and construction methods), the morphological context (terrain characteristics) and also the timeliness of the data [45] [60] [61]. It is necessary to work on a common grid rather than a specific grid for each survey. It is also important to use the same interpolators (e.g. Ordinary Kriging) applied to different topographic data sets. DEM is built at $10 \mathrm{~m}$ intervals (73 rows $\times 100$ columns) by an "exact interpolator", such as the ordinary kriging. It is a local stochastic (or geostatistical) method developed by [62] [63], with one-time databases of two date maps. The one must have almost the same value of the root of the Mean Square Error (RMSE) (Table 1 and Figure 6), a low distribution in the plain and a high distribution in the hills (Figure 7).

The map of the average interpolation errors generated by a calculation on both rasters by the following equation:

$$
\text { Mean Interpolation Errors }=\frac{1}{2}\left(z_{(1893)}+z_{(1985)}\right)
$$

This map (Figure 8) shows errors that range from 0 to $1 \mathrm{~m}$ in the plain and very high values that can reach $10 \mathrm{~m}$ in the landforms with a fairly high standard deviation of 0.6 (Table 2).

\subsubsection{Residual DEM}

The main idea behind this article is to perform a simple raster subtraction between two DEM with different dates and perfectly identical footprint. The obtained result is the arithmetic difference between the DEM of 1893 and that of 1985. As shown in the flowchart (Figure 3), the generated DEM is in "Raster" format, with image oriented data presented as a group of juxtaposed square pixels, which effectively mark the arithmetic pixel by pixel difference (GRID).

This GRID difference reflects our use of two "GRID" DEM with identical alignment and cell size used to calculate the two models generated in 1893 and 1985. However, the difference in DEM in vector format presents relatively exaggerated errors with a very rough estimate by setting the same coordinates for each point on the map where the arithmetic difference remains dependent on having the $\mathrm{Z}$ for the same points from one companion to another.
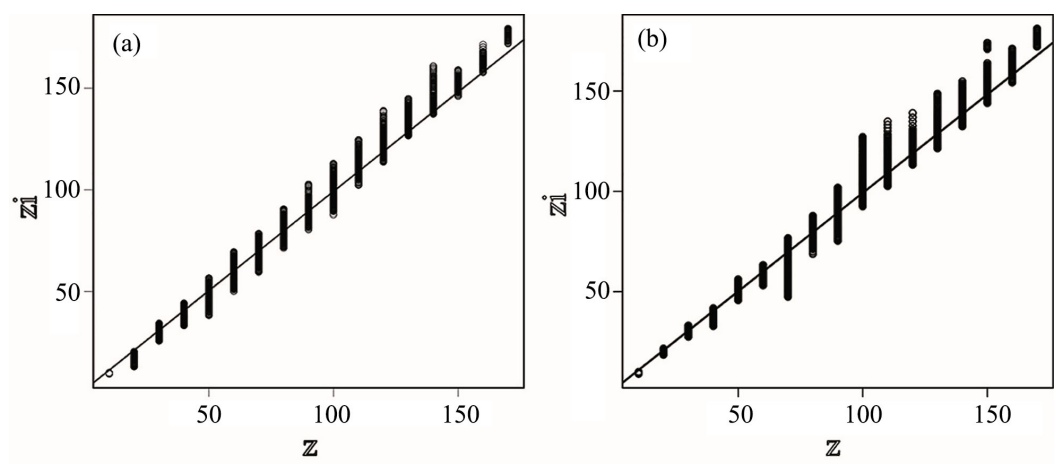

Figure 6. Distribution of altitude values, (a): 1893; (b): 1985 ( $z$. observed value; $z i$ interpolated value). 

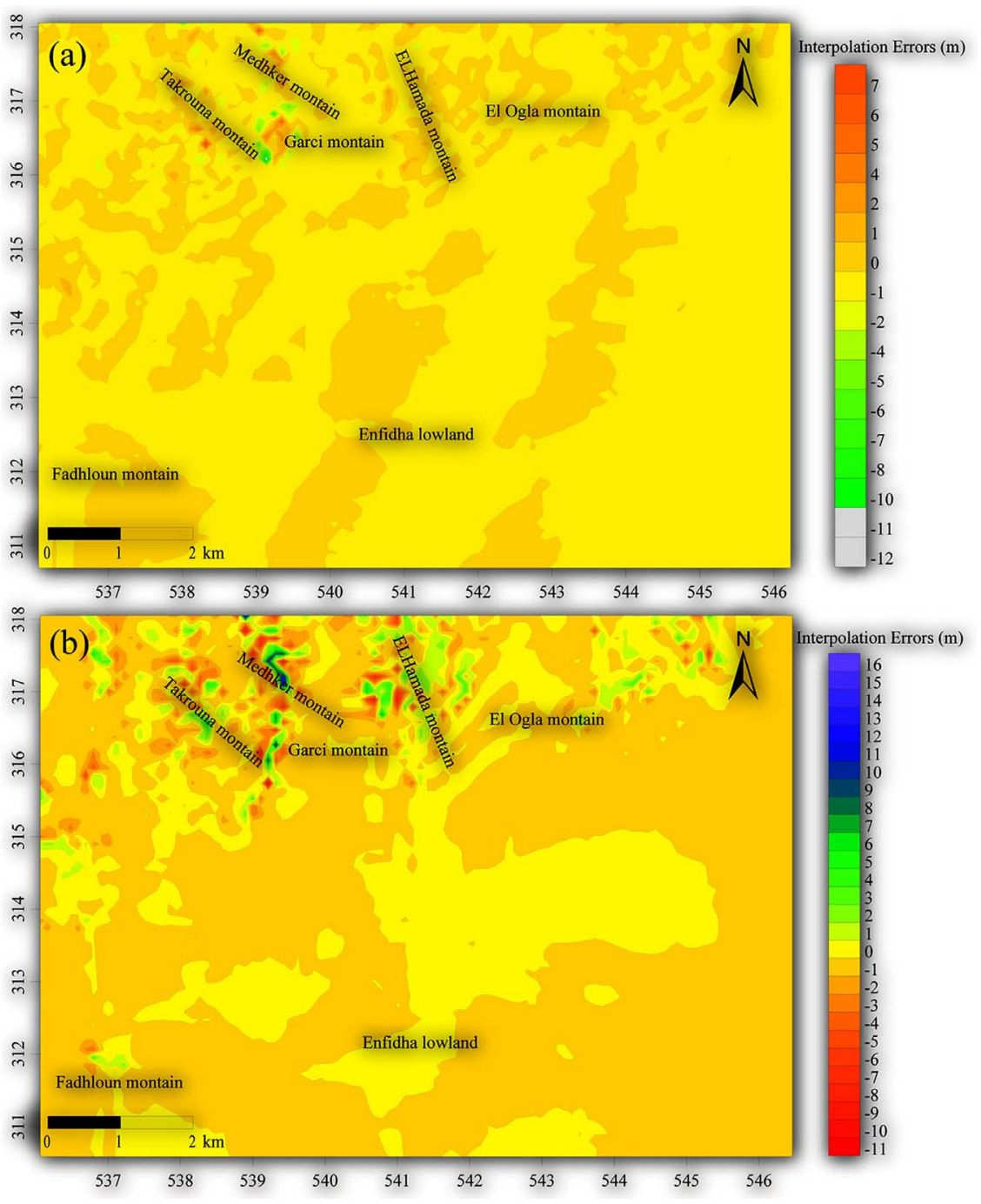

Figure 7. Lambert IGN coordinate system map for the distribution of interpolation (or residual) errors (a) 1985; (b) 1893.

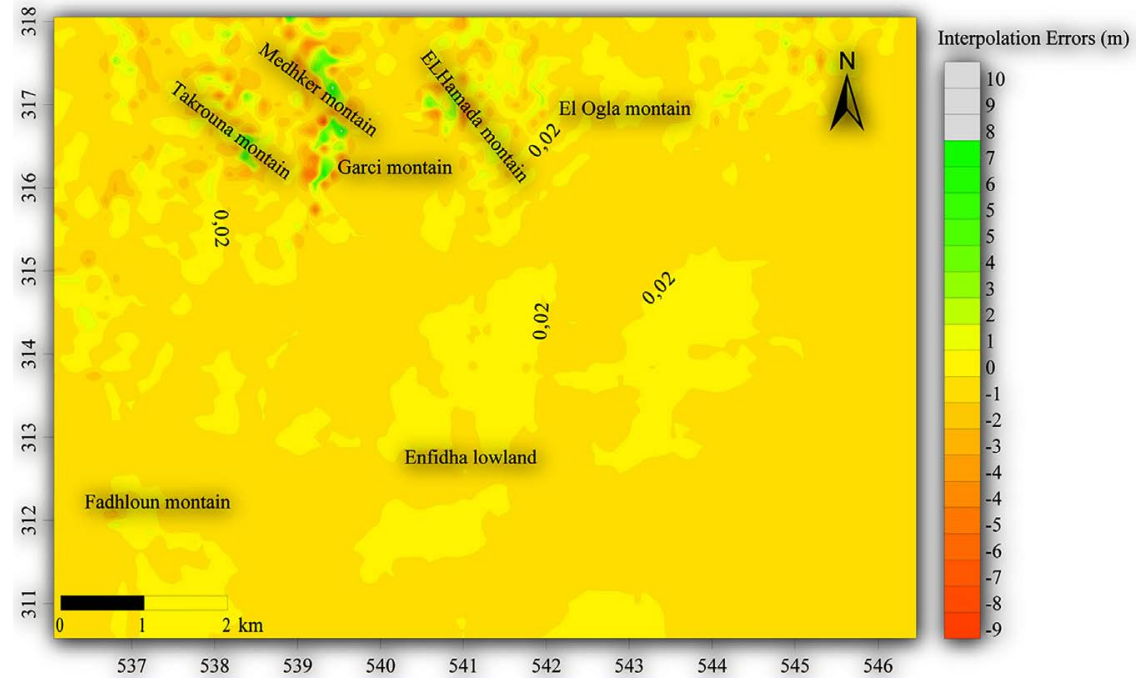

Figure 8. The map for interpolation (or residual) mean error distribution. 
Table 2. The Kriging interpolation method statistical parameters for the mean $R M S E$ error distribution.

\begin{tabular}{cccccc}
\hline & Minimum & Maximum & Mean & Median & Standard deviation \\
\hline \multirow{2}{*}{ RMSE } & -9 & 10 & -0.05 & -0.015 & 0.6 \\
\hline
\end{tabular}

We have calculated the altitude differences on the same grid and applied an interpolator to generate the DEM. The comparison of the residual between the DEM enables the visualization and quantification of the altitude variation over the entire sector. These variations involve slope or local subsidence variations [64].

The residual DEM therefore constitute a spatio-temporal database applicable to several morphological phenomena as an example for studying the coastal degradation problem as a whole [65] [66] [67] [68].

They can also be used in the calculation of sediment volumes extracted (or deposited) from successive bathymetric surveys [64] [67] [69] and in the estimation of water stock variations in the watershed [70].

\section{Results and Discussion}

\subsection{Recent Deformation Analysis by Residual (DEM)}

\subsubsection{DEM and Derived Models}

As previously mentioned in the introduction, this work is based on the analysis of recent deformations by the residual digital elevation model (DEM) that reveals morphostructural responses.

Through simple and complex spatial analyses, our methodology consists in extracting several morphometric parameters from the DEM in order to study the morphostructural behavior and the recent deformation of the investigated area.

In this study, two spatial analysis levels were performed. The first is a complex spatial analysis that allows us to identify the second and third order morphometric parameters: topographic profile, slope profile and topographic residual (Figures 9-11). All these parameters permit us to determine the morphostructural behavior and establish a geomorphological framework for the studied massifs.

The second is a simple spatial analysis that makes it possible to identify first-order morphometric parameters (slope map, relief map, three-dimensional views) (Figures 10-12).

\subsubsection{Residual Topography}

The residual topography is also a grid surface of a high analytical importance [15] [66] [68] [70]. It is produced by the arithmetic subtraction of the recent surface (1985) from the old surface of 1893 (type 1922) (Figure 9).

From the DEM, an automatic extraction is carried out according to a topographic section chosen to indicate the variation in altitude over the entire field and projected on the map. 
An examination of the residual map reveals very large topographic residual intervals between 1 and $45 \mathrm{~m}$ and between -7 and $-35 \mathrm{~m}$ that appear in the hillside mountain (Figure 9). The residual map (Figure 9) shows an estimated absolute subsidence of 3 to 7 meters in the Enfidha plain.

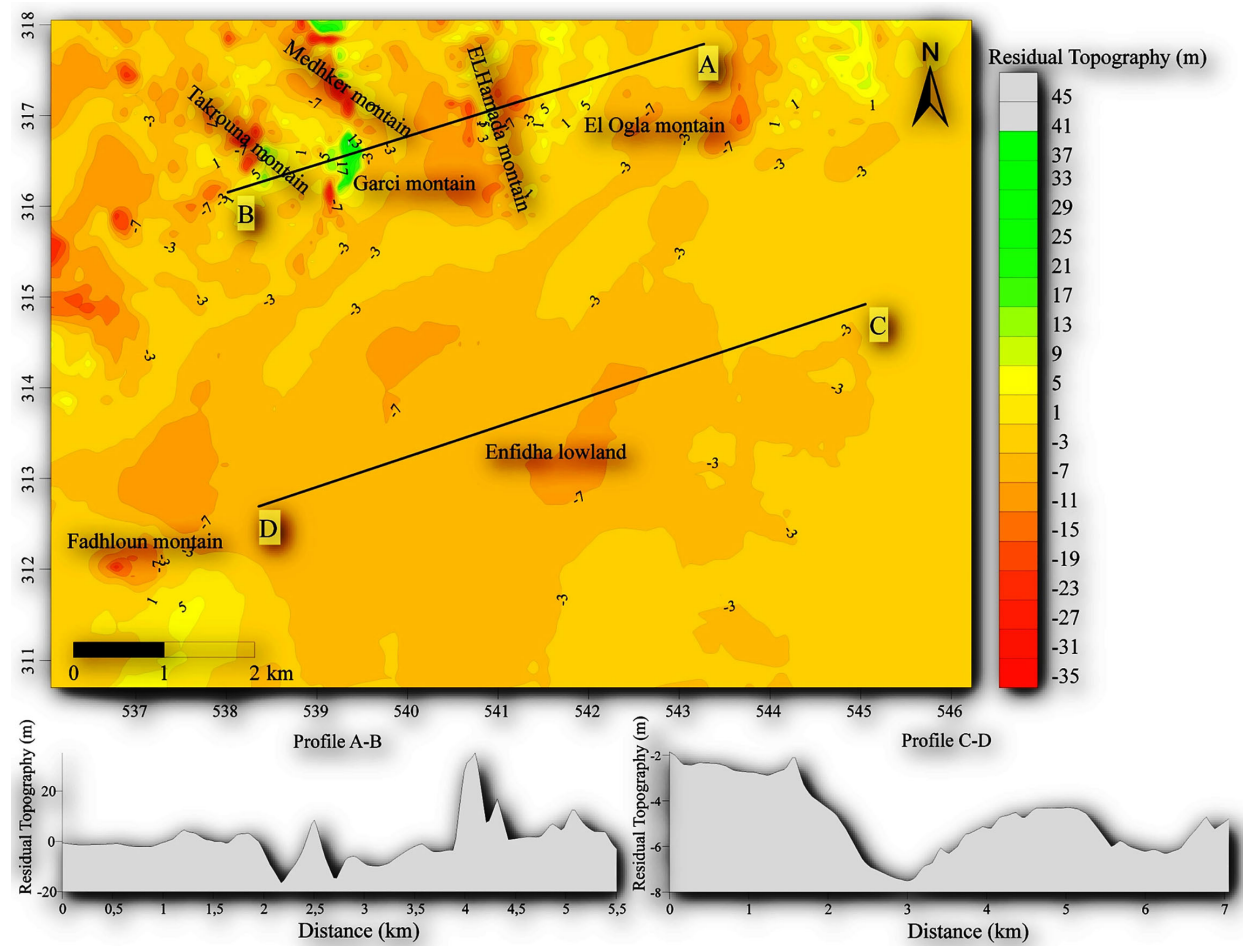

Figure 9. The residual (DEM) of topographic variation in the epoch between 1893 and 1985.
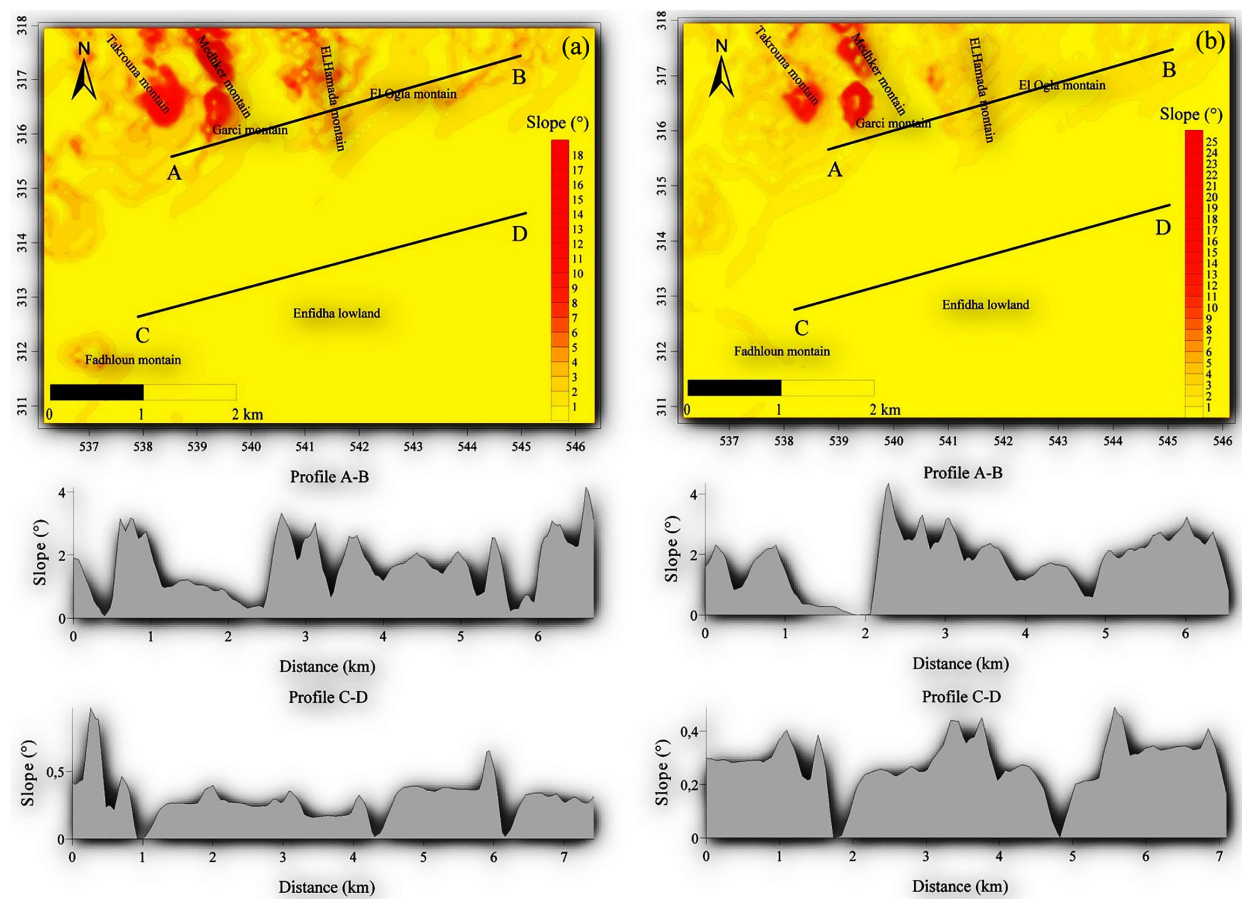

Figure 10. The slope maps (a) 1893. (b) 1985. 

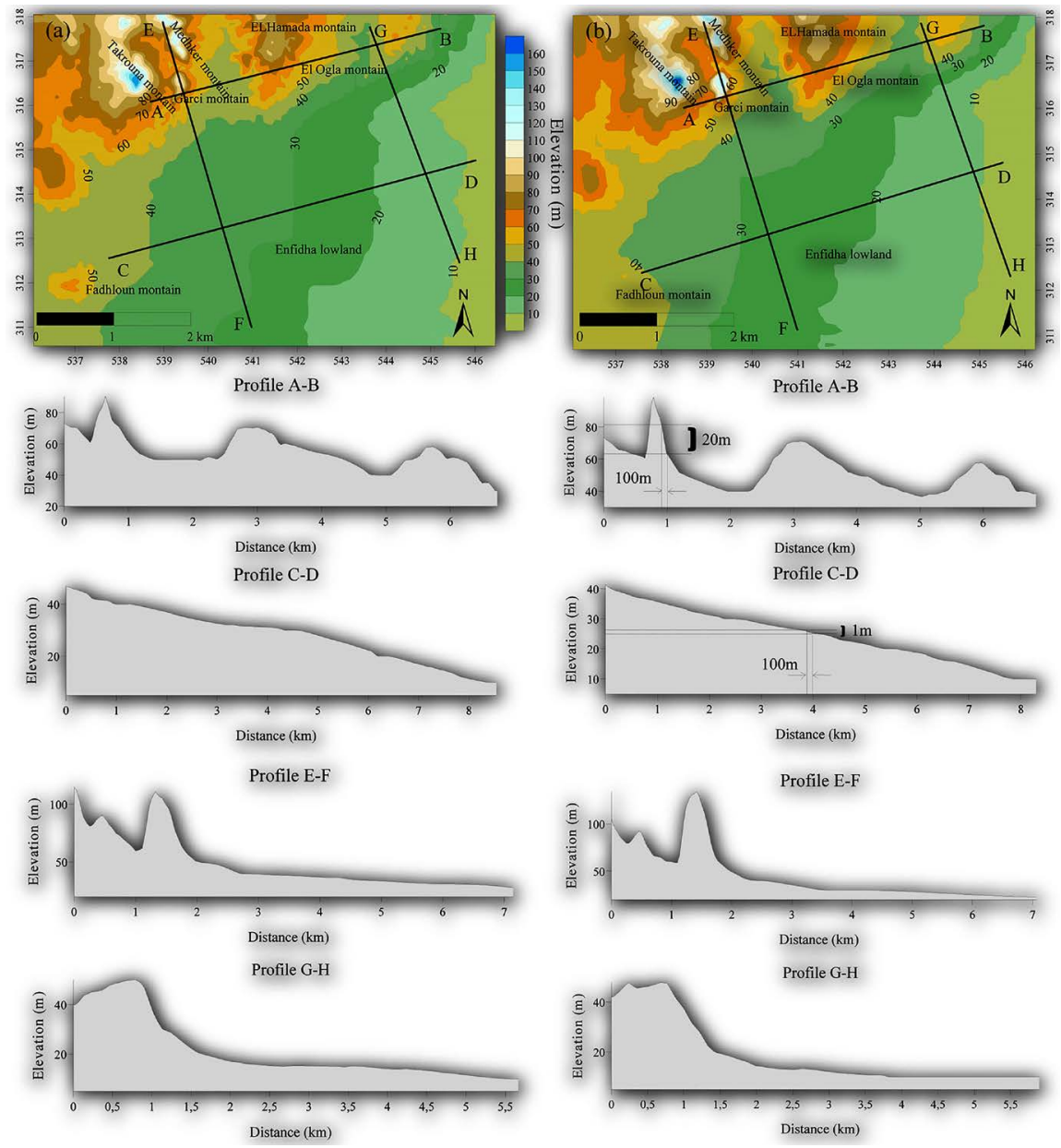

Figure 11. The topographic Maps (a) 1893; (b) 1985.

Consequently, while considering a $100 \mathrm{~m}$ shift between the line contours of 1893 (type 1922) and those of 1985, the one can either descend or rise abruptly of almost $20 \mathrm{~m}$ of altitude as shown in the topographic profile (AB) (Figure 11).

Thus, considering a $100 \mathrm{~m}$ offset between the contour lines of 1893 (type 1922 ) and those of 1985 , one can suddenly descend or rise by nearly $20 \mathrm{~m}$ in altitude as also indicated in the topographic profile (AB) (Figure 11).

In the plain, the margin of error risk is almost insignificant and a displacement of a few meters will not have a significant effect on the residue as indicated in the topographic profile (CD) (Figure 11). The altitude varies between 1 and 2 $\mathrm{m}$ for a $100 \mathrm{~m}$ displacement.

It is undeniable that taking into consideration the margin of error in georeferencing, digitization and modelling of the digital terrain model (interpolation) (Figure 11) is crucial.

\section{1) Slope distribution and morphometry of topographic profiles \\ Slope distribution}

Many authors prove that the quality of a DEM depends on the derivation degree of the geomorphological parameters which is calculated in relation to the altimetry level [71] [72] [73] [74] [75]. If the parameter is the altitude or if it is 


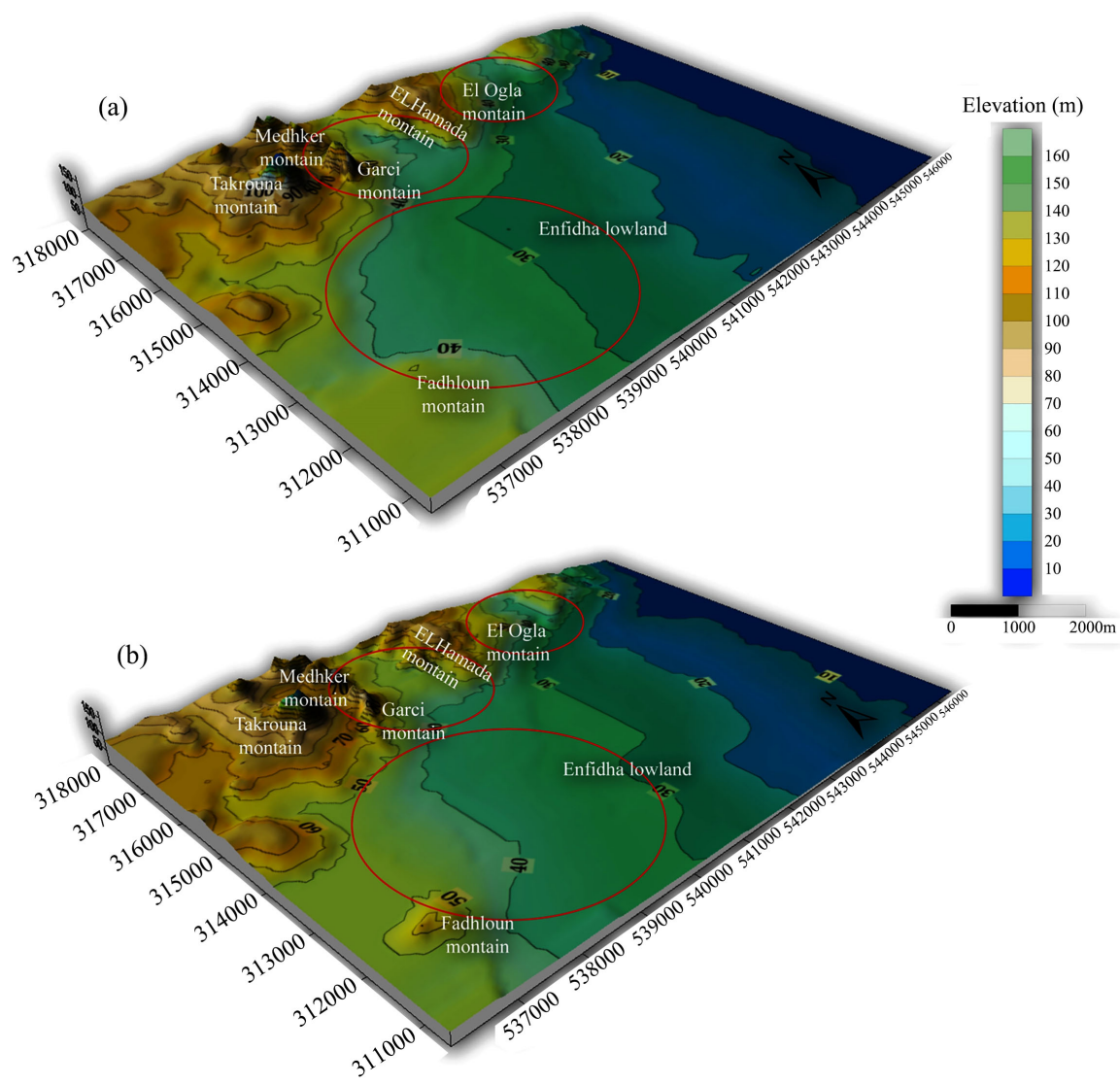

Figure 12. The synoptic view of this study area's three-dimensional models. (a) 3D Model (1985) and (b) 3D Model (1893).

calculated by the first derivatives [76] (slope, orientation) or secondary derivatives (e.g. curvatures), the obtained accuracy will be different. In order to better characterize the investigated morphostructures, we generate a grid DEM with a $10 \mathrm{~m}$ resolution. From these, we generated slope maps, relief maps, slope profiles and topographic profiles.

Subsequently, a digital contrast is applied to the produced slope map in order to highlight the slope gradients and their trend in the geologic terrain. The final products maps illustrated in figures (Figure 10, Figure 11) are a 2.5 dimension with a distribution of the slope and an elevation of the value.

Topographic and slope profiles.

The topographic and slope profiles are automatically generated from two DEM.

The idea is to extract altimetric variations or slope gradients along a topographic trace through the DEM. The comparison between the $(\mathrm{AB})$ profile (1893) and the (AB) profile (1985) illustrates the subsidence of the Enfidha plain, which is about 2 to 3 meters in height (Figure 11).

The topographic maps and profiles show two geographical compartments with a very clear morphological contrast. There are mountain ranges on the one side, and very cut-out plateaus and plains on the other (Figures 10-12). 
The mountain ranges indicate a topographic development up to 170 meters of altitude (case of Medhker Mountain) (Figure 11).

"V"-shaped valleys are very remarkable on the topographic profiles and demonstrate a strong incision and a development of very degraded interleaved rivers arranged parallel to each other and often reduced to summits of mountains and hills. The lowest of them are located at an altitude of between 50 and 60 meters as can be seen at the bottom of Medhker Mountain.

\section{2) The synoptic view of the three-dimensional models}

The synoptic view of this study area's three-dimensional models reveals a succession of geometrically different folds: El Ogla, Garci, Medhker and the Fadhloun mountains in the south and the vast Enfidha plain (Figure 12). The comparison between the two models (a) and (b) is a good indication of the subsidence, which is very apparent in the Fadhoum mountain, in the Enfidha plain and in the East of the Garci and El Ogla mountains (represented by red circles).

\subsection{The Impact of Recent Deformation on the River System}

\subsubsection{The Effect of Lithology on the Behavior of the Hydrographic Network}

In the [77] work, it is revealed that the hydrographic network configuration results from the simultaneous interactions of many and complex factors. If water is incompressible by nature and flows by the shortest path from the highest point (summit, ridge ...) to the lowest point (sea, lake, river ...), obstacles that modify its path. The causes are geologic, tectonic, climatic (paleoclimate), vegetation and human action. They have an important role in the evolution of the rivers flow paths [77]. It appears that the geomorphological context of a given area correlates with the morphology of hydrographic networks [78] [79], which makes it possible to understand the path of these networks and therefore can provide information in relation to the geomorphology of the associated areas. The analysis of (Figure 13) uncovers the fact that on the same lithological facies (Quaternary), hydrographic networks of different forms are established. For this reason, the causes of the hydrographic network layout modification are not of a pure geologic (lithological) order, but are also related to active tectonics.

\subsubsection{Geographical Classifications of the Hydrographic Network}

The geometry of the hydrographic network highlights two categories of faults.

- Evidence of E-W and NW-SE faults: The study area is marked by a main hydrographic network with a NNW-SSE direction. We also note that these rivers flow towards the endorheic zone of Enfidha. This proves a flow from NNW to the SSE. The traces of these rivers still show concavity bends to the West and convexity to the East (Figure 13).

In the entire study area, the elbow geometry is aligned in an E-W direction. This argues in favor of the existence of an E-W direction fault with dextral strike-slip.

- Evidence of the E-W and N-S faults: The hydrographic network of the Sahel 
sebkhas watersheds follows the synclinal gutters and the East-West and North-South faults in a well-regulated manner (Figure 13). Right-angled stream deviations occur at the interference corners of the two accident networks [28].

\section{Field Validation}

The obtained result from the analysis of residual DEM and hydrographic network approves the existence of subsidence in the Enfidha plain varying between 3 and $7 \mathrm{~m}( \pm 50 \mathrm{~cm})$. In the course of this analysis, we have carried out a field work in the Enfidha region to observe evidence of recent deformation. This is illustrated by the presence of recent relay tectonics, marked in particular by the morphology of the contour lines (Figure 4). We have chosen two very interesting observation sites located between the relief and the quaternary deposit of the Enfidha plain (Figure 14).

The Jgarneya region is located in the north, $6 \mathrm{~km}$ away from the town of Enfidha (Figure 14).

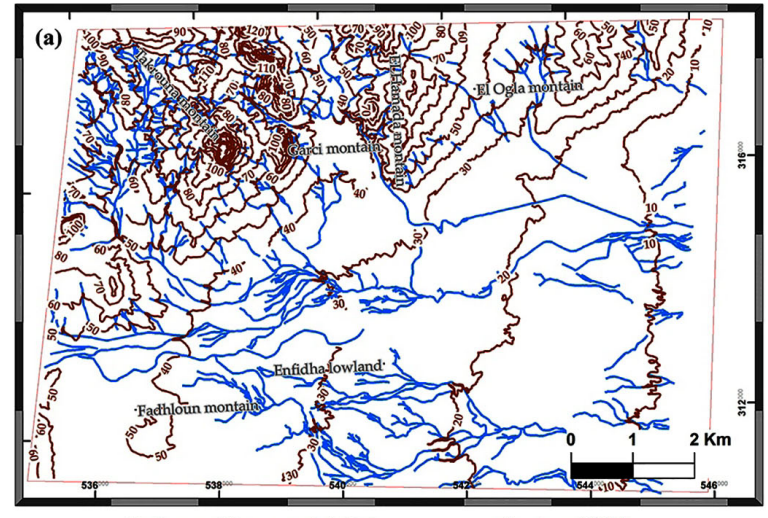

— Hydrographic network (1985) — Contour (1985)

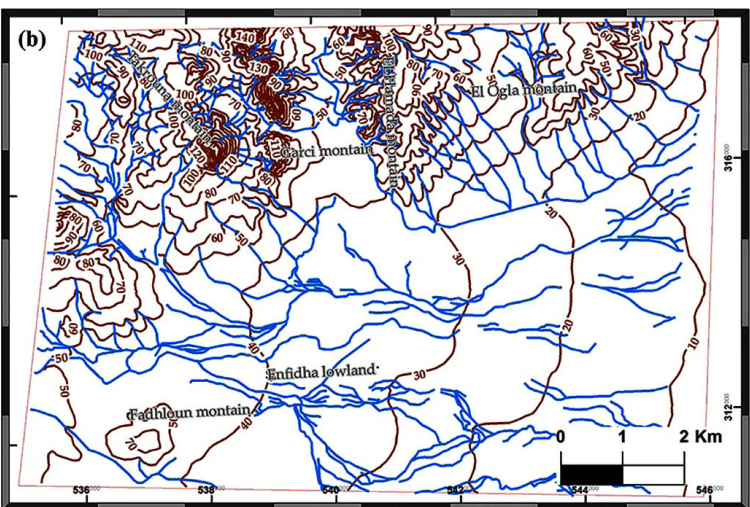

- Hydrographic network (1893)

_ Contour (1893)

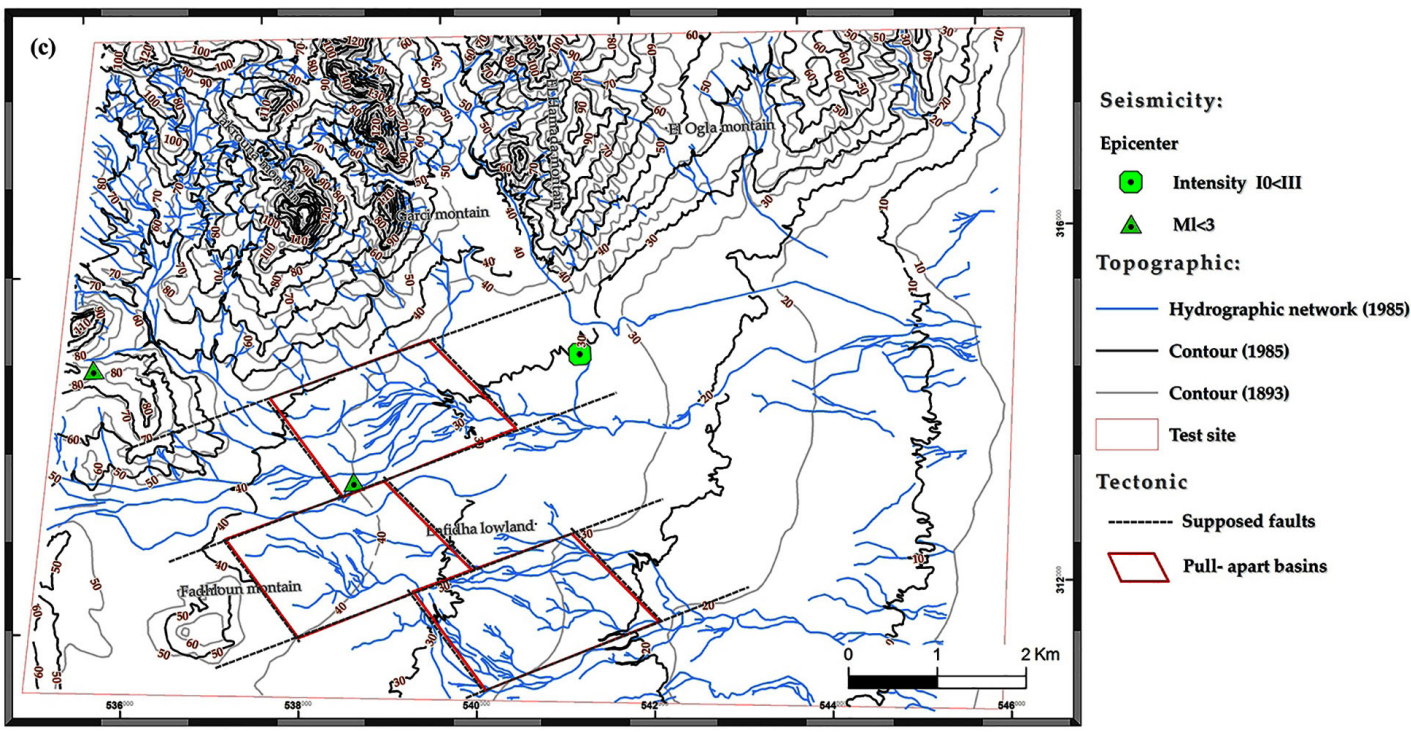

Figure 13. The geometric Parameters of Enfidha Hydrographic Networks. (a) Hydrography of 1985; (b) Hydrography of 1893 and (c) Pull-apart basins. 


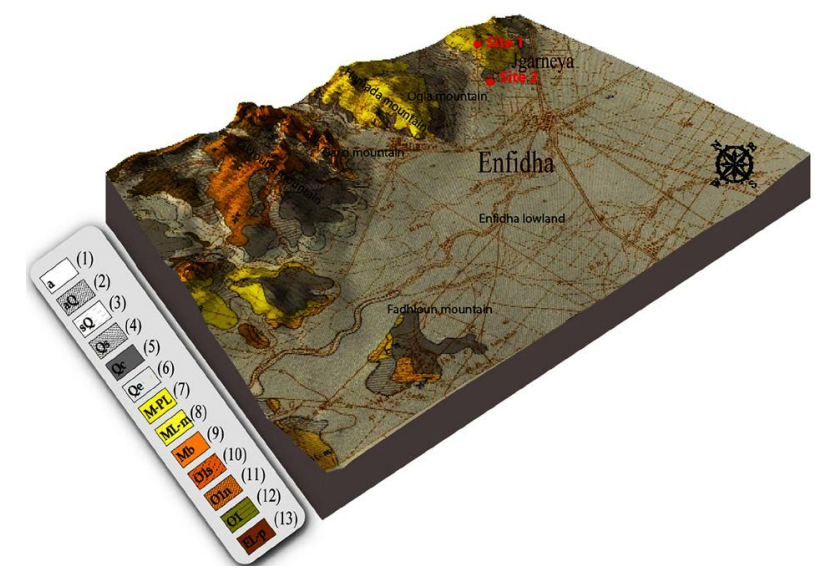

Figure 14. The location of the observation sites. (1) Recent alluvium; (2) Old alluvial deposits; (3) Soils and Sebkha; (4) Soils; (5) Crust and crusting; (6) Screes; (7) Conglomerates, sandstones and clays; (8) Sandstone with clays; (9) Sandstone limestones in Lumachelles; (10) Fine sand, sandy clay and ferruginous sandstone; (11) Nummulites and clay sandstone alternation; (12) Marly clays and sandstone; (13) Gray-green marl.

In the first observation site, an analysis of the Mio-Pliocene outcrop formed by conglomerates, sandstones and clays have been analysed. The analysis detects the presence of two combined fault networks in both directions: NE-SW and NW-SE (Figure 15 and Figure 16) as well as the set of a N120 fault showing the dextral offset with a normal set. This offset can be estimated at $25 \mathrm{~cm}$. The subsidence of SE behavior in olive trees is controlled by another fault in the N45 (NE-SW) direction (Figure 15). The fracture intensity clearly shows the distensive NE-SW and NW-SE direction regime (Figure 16).

In the second observation site, tectonic analysis shows the presence of a global fault network (Figure 17), with a sinistral normal direction of N120 and N135. The global fault network tilt a movable deposit and are filled with stony alluvium. The outcrop of Lower Miocene Lumachelle Sandstone indicates the existence of a normal fault with a direction of $\mathrm{N} 45$ and another fault with a direction of N145 affecting the Roman Ruins (Figure 17 and Figure 18).

The fracture intensity clearly shows the distensive NE-SW and NW-SE direction regime (Figure 18).

The previous work [30] indicates the existence of a subsurface fault that extends straight through the study area. On the other hand, following our observations and according to the tectonic index found, the existence of relay faults affect Miocene deposits and even Quaternary deposits, so the relative date of these faults is Miocene-Quaternary, marking an active tectonic. In the North of Enfidha, there is Henchir Jgarneya. It is the ancient Uppenna, where the ruins of an important fortress and a church are located, there is a mosaic bearing epitaphs of various bishops and martyrs is found. The Roman ruins are affected by dextral faults (N142-155), showing a lateral displacement of a few centimeters in the Hammam and the mosaics (Figure 19(d)). The calculated tensor for minor faults illustrates a strike-slip regime characterized by a $\sigma 1=\mathrm{N} 017$ and $\sigma 3=\mathrm{N} 085$ [80]. 


\section{Conclusions}

Our proposed methodology aims to quantify the variation in altitude by restoring two DEM from two topographic maps, produced at two different epochs, in 1893 and 1985. A hydrographic network, which is a complementary morphological study, is also used to reveal morphostructural responses considered as indicators of recent deformation in the case of the Enfidha region.

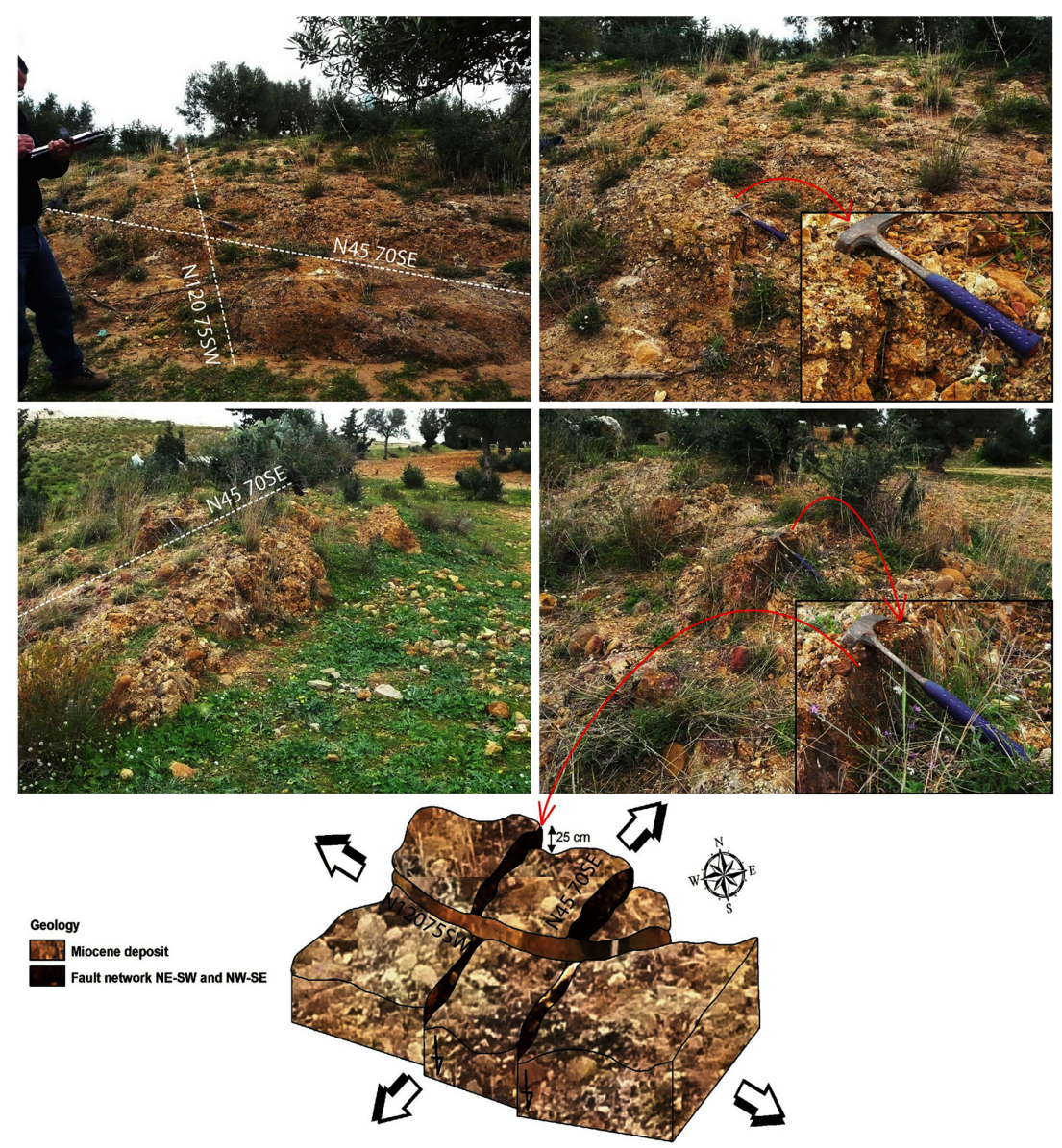

Figure 15. The fracturing Mio-Pliocene outcrops indicate the presence of NE-SW and NW-SE faulting networks.

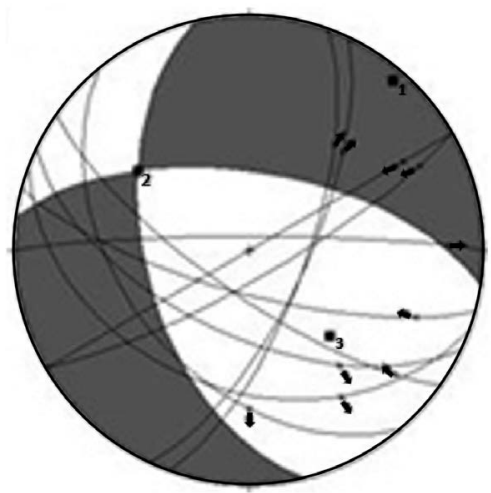

Figure 16. The fracture pattern of Mio-Pliocene outcrops. 


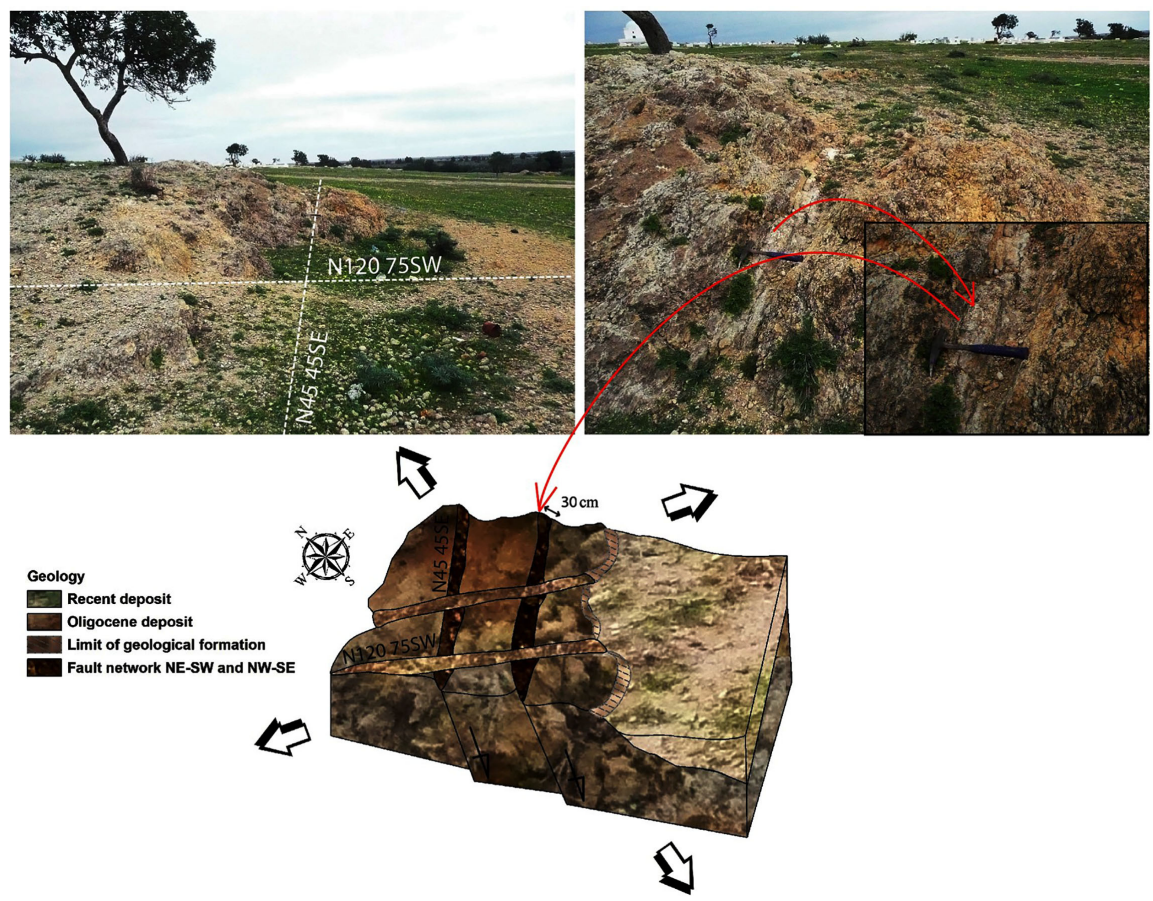

Figure 17. The Oligocene outcrop faults networks.

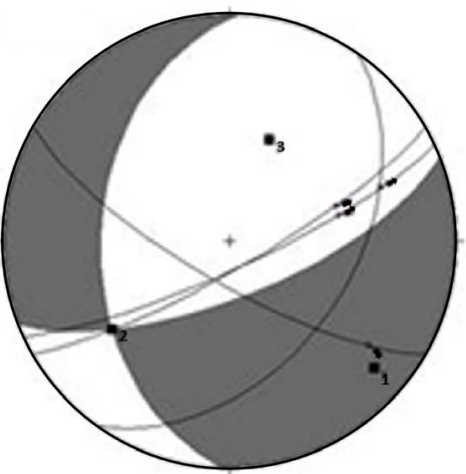

Figure 18. The fracture patterns of Oligocene outcrops.

This study is essentially based on the analysis of digital and hydrographic topographic data with automatic and semi-automatic extraction of altitude differences from the residual (DEM).

The obtained result approves the existence of subsidences in the Enfidha plain from a few meters varying between 1 and $3 \mathrm{~m}$ over a period of 100 years. On the other hand, it is necessary to be careful while evaluating the variation of altitude especially in the relief. A georeferencing or digitization error, or even a shift of the digitized contour lines by around ten meters can cause incorrect subsidence of several meters.

Field observations made in the presence of directions (N120, N135, N160) are also consistent with previous gravimetric, seismic and tectonic work and have shown the presence of underground accidents that have remained active to this day. 
(a)

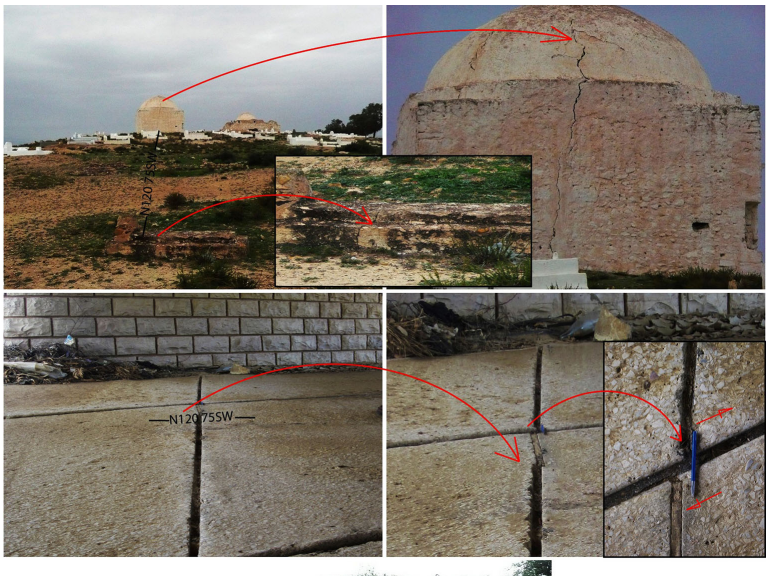

(c)

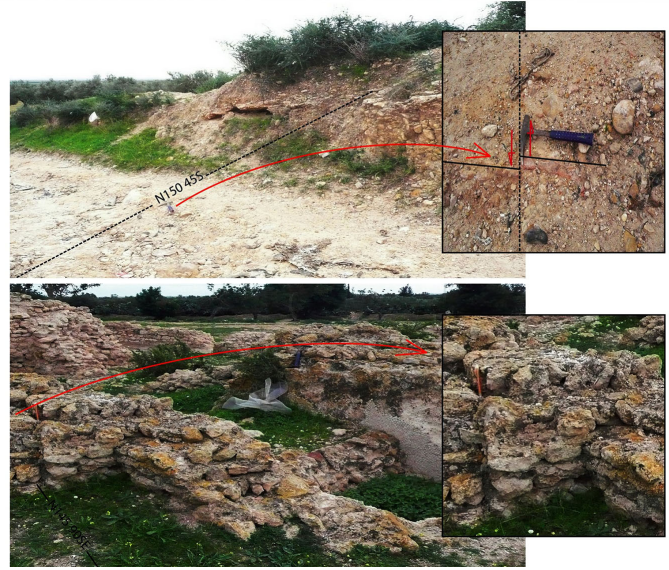

Figure 19. The neotectonics and recent deformation in the study area affect Marabouts and Tombs (a); Bridge at the Entrance of Enfidha (b); Current deposits (c) and Roman Ruins (d).

We conclude that the analysis of recent deformations by GIS is significant and promising. However, the results can be improved by setting up a GPS surveillance network that allows direct measurements of recent deformation.

\section{Acknowledgements}

The authors warmly thank Mohamed Raouf Karray from the 9th April Faculty of Tunis, Mohamed Moncef Turki and Mohamed Ben Chelbi from the geologic Department of the Faculty of Sciences of Tunis for agreeing to provide us with the necessary data and to help us to analyse the observations of the field work. We also appreciate the collaboration of the Tunisian geologic Office (National Office of Mines), which provided us with the geologic map.

\section{Conflicts of Interest}

The authors declare no conflicts of interest regarding the publication of this paper.

\section{References}

[1] Jauzein, A. (1967) Contributionà l'étude géologique des confins de la dorsale Tuni- 
sienne (Tunisie Septentrionale). République tunisienne, Secrétariat d'état au plan et à l'économie nationale, Tunis.

[2] Ben Ayed, N. (1986) Evolution tectonique de l'avant-pays de la chaîne alpine de Tunisie du début du Mésozoïque à l'Actuel These de doctorat en géologie, Universit Paris Sud-Paris XI, 327.

[3] Tlig, S., Erraioui, L., Ben Aissa, L. and Aluoani Ret, A.M. (1991) Tectogenèses alpine et atlasique: Deux événements distincts dans l'histoire géologique de la Tunisie. Corrélation avec les événements clés en Méditerranée. Comptes Rendus de P Académie de Sciences, 295-301.

[4] Boukadi, N. and Bedir, M. (1996) Déformation discontinue rotation et plissement concentrique. Exemple de l'Atlas Tunisien et du bloc pélagien. Revu Tunisienne de Pénergie, 2233.

[5] Ben Chelbi, M., Kamel, S., Harrab, S., Rebai, N., Melki, F., Meghraoui, M., et al. (2013) Tectonosedimentary Evidence in the Tunisian Atlas, Bou Arada Trough: Insights for the Geodynamic Evolution and Africa-Eurasia Plate Convergence. Journal of the Geological Society, 170, 435-449. https://doi.org/10.1144/jgs2012-095

[6] Dlala, M. (1995) Evolution géodynamique et tectonique superposées en Tunisie: implication sur lévolution géodynamique récente et la sismicité. Thèse Es Science Géologique, Tunis University, Tunis, 389.

[7] Chihi, L. (1995) Les fossés néogènes à quaternaires de la Tunisie et de la mer pélagienne: leur étude structurale et leur signification dans le cadregéodynamique de la Méditerranée Centrale. Thèse Doctorat en Sciences, Facult des Sciences de Tunis, Universit Tunis II, Tunis, 566.

[8] Biju-Duval, B., Dercourt, J. and Le Pichon, X. (1977) From the Tethys Ocean to the Mediterranean Seas: A Plate Tectonic Model of the Evolution of the Western Alpine System. Histoire structurale des bassins méditerranéens, 143-164.

[9] Dercourt, J., Zonenshain, L.P., Ricou, L.E., Kazmin, V.G., Le Pichon, X., Knipper, A.L., et al. (1985) Presentation de 9 cartes paleogeographiques au 1/20000000000eme s'etendant de l'Atlantique au Pamir pour la periode du Lias a l'Actuel. Bulletin de la Socit Gologique de France, I, 637.

[10] Pazzaglia, F.J. (1989) Tectonic and Climatic Inuences on the Evolution of Quaternary Depositional Landforms along a Segmented Range-Front Fault, Sangre de Cristo Mountains, North-Central New Mexico. University of New Mexico, Albuquerque, New Mexico, 246.

[11] Rabia, M.C. (1998) Système d'information géoscientifique et télédétection multicapteurs: Application à une étude multi-thèmes de la Jeffara orientale. Thèse de Doctorat d'tat en Sciences, These de doctorat en géologie, Faculté des Sciences de Tunis, Université Tunis El Manar, Tunis, 320.

[12] Delcaillau, B. (2004) Reliefs et tectonique récente, Nouveau Précis de Géomorphologie. Vuibert, Paris, 264.

[13] Grohmann, C.H. (2004) Morphometric Analysis in Geographic Information Systems: Applications of Free Software GRASS and R. Computers \& Geosciences, 30, 1055-1067. https://doi.org/10.1016/j.cageo.2004.08.002

[14] Peters, G. and van Balen, R.T. (2007) Tectonic Geomorphology of the Northern Upper Rhine Graben, Germany. Global and Planetary Change, 58, 310-334. https://doi.org/10.1016/j.gloplacha.2006.11.041

[15] Rebai, N., Slama, T. and Turki, M.M. (2007) Evaluation de différentes méthodes d'interpolation spatiale pour la production d'un MNT à partir de données topogra- 
phiques dans un SIG. $X Y Z, 110,19-28$.

[16] Van Westen, C.J., Castellanos, E. and Kuriakose, S.L. (2008) Spatial Data for Landslide Susceptibility, Hazard, and Vulnerability Assessment: An Overview. Engineering Geology, 102, 112-131. https://doi.org/10.1016/j.enggeo.2008.03.010

[17] Slama, T. (2008) Conception orienté objet dun SIG pour lanalyse quantitative morphostructurale et morpho-néotectonique (tectonique active) de la partie nord-est de la zone des diapirs, Tunisie septentrionale, méthode numérique et applications. These de doctorat en géologie, Université de Tunis El Manar, Tunis, 476.

[18] Nigel, R. and Rughooputh, S.D. (2010) Soil Erosion Risk Mapping with New Datasets: An Improved Identification and Prioritisation of High Erosion Risk Areas. Catena, 82, 191-205. https://doi.org/10.1016/j.catena.2010.06.005

[19] Ben Hassen, M. (2012) Analyse de la déformation récente dans l'Atlas méridional de la Tunisie par géomorphométrie et Interférométrie Radar (DInSAR). These de doctorat en géologie, Paris Est, 345.

[20] Achour, H. (2013) Du contrle de la qualité du MNT à l'analyse morphotectonique: Approches croisées SIG et Statistique. (Méthodes numérique et applications). Thèse de doctorat en Génie de l'environnement et de l'aménagement. Université de Sfax. Ecole Nationale d'Ingénieurs de Sfax, 273.

[21] Ouerghi, S. (2014) Intégration des données multisources (Géologiques, sismologiques, géophysiques et géomorphomètrique) dans un environnement SIG. These de doctorat en géologie, Faculté des Sciences de Tunis, Université de Tunis El Manar II, Tunis, 300.

[22] Vernet, J. (1981) Esquisses paléogéographiques de la Tunisie Durant lOligocène et le Miocène inférieur. Actes du Premier congrès national des sciences de la Terre, Tunis, 231-244.

[23] Haller, P. (1983) Structure profonde du Sahel tunisien. Interprétation géodynamique. Thèse de Doctorat de 3ème cycle, Université de Franche-Comté, Besançon, France, 162.

[24] Bédir, M. (1995) Mècanismes gèodynamiques des bassins associès au couloir de coulissements de la marge atlasique de la Tunisie: seismo-stratigraphie, seismotectonique et implications pétrolières. These de doctorat en gèologie, Facultè des Sciences de Tunis, Universitè de Tunis El Manar II, Tunis, 416.

[25] Burollet, P.F. (1956) Signification géologique de l'axe Nord-Sud. Actes du 1er Congrès Nat. Sci Terre Tunisie. 315-319.

[26] Burollet, P.F. (1981) Signification géologique de l'Axe Nord-Sud. 1er Cong. Nat. Sc. Terre, Tunis.

[27] Bédir, M. (1988) Géodynamique des bassins sédimentaires du Sahel de Mahdia (Tunisie orientale) de l'Aptien à l'actuel. Sismostratigraphie, Sismotectonique et Structurale. Répercutions pétrolières, hydrologiques et sismiques. Thèse de Doctorat 3ème cycle, Faculté des Sciences de Tunis, Université de Tunis El Manar II, Tunis.

[28] Amari, A. and Bédir, M. (1989) Les bassins quaternaires du Sahel central de la Tunisie, genèse et évolution des sebkhas en contexte décrochant compressif et distensif. RevGéodyn, 4, 49-65.

[29] Boukadi, N. (1994) Structuration de l'Atlas de Tunisie: signification géométrique et cinématique des net des zones d'interférences structurales au contact des grands couloirs tectoniques. Thèse de Doctorat 3ème cycle, Faculté des Sciences de Tunis, Université de Tunis El Manar II, Tunis. 
[30] Khomsi, S., B_edir, M., Ben Jemia, M.G. and Zouari, H. (2004) Mise en évidence d'un nouveau front de chevauchement dans l'Atlas tunisien oriental de Tunisie par sismique réflexion. Contexte structural régional et rle du Trias salifère. Comptes Rendus Geoscience, 336, 1401-1408. https://doi.org/10.1016/j.crte.2004.06.007

[31] Gabtni, H. (2005) Apport de la gravimétrie à l'étude des structures profondes du Sahel de Tunisie (cas de la région de Kairouan-Sousse-Monastir). Comptes Rendus Geoscience, 337, 1409-1414. https://doi.org/10.1016/j.crte.2005.09.007

[32] Hadj Sassi, M., Zouari, H. and Jallouli, C. (2006) Contribution de la gravimétrie et de la sismique réflexion pour une nouvelle interprétation géodynamique des fossés d'effondrement en Tunisie: Exemple du fossé de Grombalia. Comptes Rendus Geoscience, 338, 751-756. https://doi.org/10.1016/j.crte.2006.07.005

[33] Ghribi, R. and Bouaziz, S. (2010) Neotectonic Evolution of the Eastern Tunisian Platform from Paleostress Reconstruction. Journal of Hydrocarbons, Mines and Environmental Research, 1, 14-25.

[34] Hezzi, I. (2014) Caractérisation géophysique de la plateforme de Sahel, Tunisie nord orientale et ses conséquences géodynamiques. Thèse de Doctorat de 3ème cycle, Faculté des Sciences de Tunis, Université de Tunis El Manar II, Tunis, 315.

[35] Kamoun, Y. (1981) Néotectonique dans la région de Monastir-Mahdia (Tunisie orientale). Thèse de Doctorat 3ème cycle, Université Paris-Sud, Orsay, France, 175.

[36] Delteil, J., Zouari, H., Chikhaoui, M., Creuzot, G., Ouali, J., Turki, M.M., et al. (1991) Relation entre ouvertures téthysienne et mésogéenne en Tunisie. Bulletin de la Société Géologique de France, 162, 1173-1181.

[37] Kamoun, Y. (2001) Un témoin de l'importante lunette d'El Kelbia: Draa Lakhmès-Ech Chraf (Tunisie orientale). Notes du Service Géologique de Tunisie, 67, 107-119.

[38] Zargouni, F. and Abbes, C. (2010) La zonation structurale de la Tunisie. Centre des Sciences de la Terre. INRST, Borj Cedria, 63-69.

[39] Bedir, M. and Zargouni, F. (1986) Post-Miocene Structuration of Mahdia Sahel Sedimentary Banks: Geometric and Kinematic Analysis of Subsurface Data. Earth Sciences Journal, 4, 55-69.

[40] Karray, M.R. (2006) Soil Movements in the Hinterland of the Gulf of Hammamet (Tunisia). Tunisian Journal of Geography, 12, 75-104.

[41] Chakhar, S. (2006) Cartographie décisionnelle multicritére: formalisation et implémentation informatique. Thèse de doctorat, Universite Paris Dauphine-Paris IX, 301.

[42] Miller, C.L. and Laamme, R.A. (1958) The Digital Terrain Model-: Theory \& Application. MIT Photogrammetry Laboratory, Cambridge, MA, 20.

[43] Theobald, D. and Goodchild, M. (1990) Artifacts of TIN-Based Surface Flow Modeling. Proceedings of GIS/LIS, 90, 955-964.

[44] Siddiqui, S., Castaldini, D. and Soldati, M. (2017) DEM-Based Drainage Network Analysis Using Steepness and Hack SL Indices to Identify Areas of Differential Uplift in Emilia-Romagna Apennines, Northern Italy. Arabian Journal of Geosciences, 10, 3. https://doi.org/10.1007/s12517-016-2795-x

[45] Charleux-demargne, J. (2001) Qualité des Modèles Numériques de Terrain pour l'HydrologieApplication à la Caractérisation du Régime de Crues des Bassins Versants. Thèse préparée au sein de l'Unité Mixte de Recherche Structures et Systèmes Spatiaux, Cemagref-Engref, Montpellier.

[46] Zhou, Q., Lees, B. and Tang, G. (2008) Advances in Digital Terrain Analysis. In: 
Lecture Notes in Geoinformation and Cartography, Springer, New York, 472. https://doi.org/10.1007/978-3-540-77800-4

[47] Ben Hassen, M., De_ontaines, B. and Turki, M.M. (2014) Recent Tectonic Activity of the Gafsa Fault through Morphometric Analysis: Southern Atlas of Tunisia. Quaternary International, 338, 99-112. https://doi.org/10.1016/j.quaint.2014.05.009

[48] Sarp, G. and Duzgun, S. (2015) Morphometric Evaluation of the Afşin-Elbistan Lignite Basin Using Kernel Density Estimation and Getis-Ord's Statistics of DEM Derived Indices, SE Turkey. Journal of Asian Earth Sciences, 111, 819-826. https://doi.org/10.1016/j.jseaes.2015.07.022

[49] Chaieb, A., Rebai, N., Ghanmi, M.A., Moussi, A. and Bouaziz, S. (2017) Spatial Analysis of River Longitudinal Profils to Cartography Tectonic Activity in Kasserine Plain Tunisia. Geographia Technica, 12, 30-40.

https://doi.org/10.21163/GT_2017.122.04

[50] Moussi, A., Rebaï, N., Chaieb, A. and Saâdi, A. (2018) GIS-Based Analysis of the Stream Length-Gradient Index for Evaluating Effects of Active Tectonics: A Case Study of Enfidha (North-East of Tunisia). Arabian Journal of Geosciences, 11, 123. https://doi.org/10.1007/s12517-018-3466-x

[51] Duclos, P.A. (2012) Impacts morpho-sédimentaires de l'extraction de granulats marins-application au bassin oriental de la manche. Thèse de doctorat, Université de Rouen, France, 272.

[52] Doty, L.A. (1996) Statistical Process Control. Industrial Press Inc., New York, 379.

[53] Li, Z. (1988) On the Measure of Digital Terrain Model Accuracy. The Photogrammetric Record, 12, 873-877. https://doi.org/10.1111/j.1477-9730.1988.tb00636.x

[54] Shearer, J. (1990) The Accuracy of Digital Terrain Models. Terrain Modeling in Surveying and Engineering. Whittles Publishing Services, Caithness, 315-336.

[55] Hunter, G.J. and Goodchild, M.F. (1997) Modeling the Uncertainty of Slope and Aspect Estimates Derived from Spatial Databases. Geographical Analysis, 29, 35-49. https://doi.org/10.1111/j.1538-4632.1997.tb00944.x

[56] Fisher, P.F. (1998) Improved Modelling of Elevation Error with Geostatistics. GeoInformatica, 2, 215-233. https://doi.org/10.1023/A:1009717704255

[57] Ostman, A. (1987) Quality Control of Photogrammetrically Sampled Digital Elevation Models. The Photogrammetric Record, 12, 333-341. https://doi.org/10.1111/j.1477-9730.1987.tb00579.x

[58] Wood, J. (1996) The Geomorphological Characterisation of Digital Elevation Models. Ph.D. Thesis, University of Leicester, Leicester, 466.

[59] Kholladi, M.K. (1999) Modèle Numérique de Terrain par la Triangulation de Delaunay avec Contraintes. In: Sminaire International sur les SIGs du conseil national de PInformation gographique (CNIG 1999), 18.

[60] Fisher, P.F. and Tate, N.J. (2006) Causes and Consequences of Error in Digital Elevation Models. Progress in Physical Geography, 30, 467-489. https://doi.org/10.1191/0309133306pp492ra

[61] Wechsler, S.P. and Kroll, C.N. (2006) Quantifying DEM Uncertainty and Its Effect on Topographic Parameters. Photogrammetric Engineering \& Remote Sensing, 72, 1081-1090. https://doi.org/10.14358/PERS.72.9.1081

[62] Matheron, G. (1963) Principles of Geostatistics. Economic Geology, 58, 1246-1266. https://doi.org/10.2113/gsecongeo.58.8.1246

[63] Matheron, G. (1970) La Théorie des variables régionalisées, et ses applications. Les 
cahiers du centre de morphologie mathématique de Fontainebleau, Ecole Nationale Supérieure des Mines. Cahiers du Centre de morphologie mathématique de Fontainebleau, 5. Ecole Nationale Supérieure des Mines de Paris, Paris, 1-212.

[64] De Chambure, L. (2011) Calcul de volumes sédimentaires extraits (ou déposés) à partir de levés bathymétriques successifs. Livre Pilier Unité Géosciences Marines Ifremer, 14.

[65] Gvirtzman, Z. and Nur, A. (2001) Residual Topography, Lithospheric Structure and Sunken Slabs in the Central Mediterranean. Earth and Planetary Science Letters, 187, 117-130. https://doi.org/10.1016/S0012-821X(01)00272-2

[66] Levacher, D. and Maron, P. (2002) VIIèmes Journées Nationales Génie Cotier-Génie Civil Anglet 2002. Paralia, Pieria.

[67] Crosby, A. and McKenzie, D. (2009) An Analysis of Young Ocean Depth, Gravity and Global Residual Topography. Geophysical Journal International, 178, 1198-1219. https://doi.org/10.1111/j.1365-246X.2009.04224.x

[68] Yahyaoui, Z. and Rebai, N. (2014) Étude de lévolution morphosédimentaire à court et moyen terme du système dune/plage de Korba (fa, cade orientale du Cap Bon, Tunisie). Revue internationale de géomatique, 24, 471-500.

[69] Winterbourne, J., White, N. and Crosby, A. (2014) Accurate Measurements of Residual Topography from the Oceanic Realm. Tectonics, 33, 982-1015. https://doi.org/10.1002/2013TC003372

[70] Thibaud, G., Gilbert, F., Jacques, H., Guillaume, F., Bernard, C.L.B.E. (2011) valuation de l'érosion du site de Wankama (Niger) par comparaison de differents MNT. Revue $X Y Z, 129,17-24$.

[71] Puech, C. (1993) Détermination des états de surface par télédétection pour caractériser les écoulements des petits bassins versants: Application à des bassins en zone méditerranéenne et en zone tropicale sèche. Université Grenoble Alpes, France, 202.

[72] Wood, J. and Fisher, P. (1993) Assessing Interpolation Accuracy in Elevation Models. IEEE Transactions on Computer Graphics and Applications, 13, 48-56. https://doi.org/10.1109/38.204967

[73] Lagacherie, P., Moussa, R., Cormary, D. and Molenat, J. (1996) Effects of DEM Data Source and Sampling Pattern on Topographical Parameters and on a Topography-Based Hydrological Model. Application of Geographic Information Systems in Hydrology and Water Resources Management, 235, 191-200.

[74] Florinsky, I.V. (1998) Accuracy of Local Topographic Variables Derived from Digital Elevation Models. International Journal of Geographical Information Science, 12, 47-61. https://doi.org/10.1080/136588198242003

[75] Wise, S.M. (1998) The Effect of GIS Interpolation Errors on the Use of Digital Elevation Models in Geomorphology. In: Lane, S.N., Richards, K.S. and Chandler, J.H., Eds., Landform Monitoring, Modelling and Analysis, Wiley, New York, 139-164.

[76] Achour, H., Rebai, N., Driessche, J. and Bouaziz, S. (2012) Modelling Uncertainty of Stream Networks Derived from Elevation Data Using Two Free Softwares: R and SAGA. Journal of Geographic Information System, 4, 153-160. https://doi.org/10.4236/jgis.2012.42020

[77] Le Pape, S. (1998) Analyse et quantification du réseau hydrographique, le réseau hydrographique comme objet vectoriel (Mémoire). École supérieure des géomètres et topographes, Le Mans, France, 66.

[78] Riazanoff, S. (1989) Extraction et analyse automatiques de reseaux a partir de mod- 
eles numeriques de terrain. Contributions a l'analyse d'image de teledetection. These de doctorat, océan, Espace, Paris, 41.

[79] Deffontaines, B. (1990) Development d'une méthodologie morphoneotectonique et morpho-structurale, analyse des surfaces enveloppes du réseau hydrographique et des MNT. Thése de doctorat, Université Paris, Paris, 229.

[80] Bahrouni, N., Bouaziz, S., Soumaya, A., Ben Ayed, N., Attafi, K., Houla, Y., et al. (2014) Neotectonic and Seismotectonic Investigation of Seismically Active Regions in Tunisia: A Multidisciplinary Approach. Journal of Seismology, 18, 235-256. https://doi.org/10.1007/s10950-013-9395-y 